Research Article

\title{
Influence of Soybean Oil on Binder and Warm Mixture Asphalt Properties
}

\author{
Rezvan Babagoli $\mathbb{D}^{1}$ and Alireza Ameli $\mathbb{D}^{2}$ \\ ${ }^{1}$ Faculty of Civil Engineering, University of Science and Technology of Mazandaran, Behshahr, Iran \\ ${ }^{2}$ Department of Civil Engineering, Faculty of Engineering, Malard Branch, Islamic Azad University, Malard, Tehran, Iran
}

Correspondence should be addressed to Rezvan Babagoli; rezvan_babagoli@civileng.iust.ac.ir

Received 2 June 2021; Revised 6 August 2021; Accepted 6 September 2021; Published 22 September 2021

Academic Editor: Raghu V. Anjanapura

Copyright ( $) 2021$ Rezvan Babagoli and Alireza Ameli. This is an open access article distributed under the Creative Commons Attribution License, which permits unrestricted use, distribution, and reproduction in any medium, provided the original work is properly cited.

\begin{abstract}
To produce a usual hot mix asphalt, significant amount of energy is used, which causes air pollution. As a result, warm mix asphalt (WMA) is introduced to reduce the mixing and compaction temperature of the mixture. On the one hand, accumulation of waste oil in the ground occupies a large space in the Earth. After the process of frying the oil, if the by-product is not controlled properly, it leads to the pollution of the environment. Hence, utilization of this waste oil can be considered as a sustainable path to dealing with the risk. The main goal of the current research is to evaluate the possibility of exploiting soybean oil to reduce the mixing and compaction temperature of mixtures and produce warm mix asphalt (WMA). Moreover, the rheological and performance properties of mixtures containing soybean are evaluated in this study. The AC-60/70 and 85/100 binders are modified by soybean oil $(0 \%, 1.5 \%, 2.5 \%$, and $3.5 \%$ by weight of binder). Several binder tests are used to measure the physical and rheological behaviors of binders, such as penetration grade, softening point, temperature susceptibility, rotational viscosity (RV), Multiple Stress Creep Recovery (MSCR), and Linear Amplitude Sweep (LAS) tests. Besides, several mixture tests are used to evaluate the performance of the mixture, including four-point bending beam fatigue (FPB), resilient modulus (Mr), indirect tensile strength (ITS), dynamic creep, and wheel track tests. Through MSCR test results, at two stress levels, the Jnr parameter increases as the soybean oil is added to the binder. The results of the LAS test revealed that the fatigue life of binders increases by addition of soybean oil. There is no significant difference between the results of new and waste oil. This in turn makes possible reducing soybean oil production and consumption, and instead frying oil (waste) is reused, which displays no significant difference in terms of chemical and physical properties. Also, the performance test of mixtures indicated that as the soybean oil is added to the mixture, the rutting performance decreases and fatigue performance increases. Based on the results, it is recommended to use $1.5 \%$ soybean oil in asphalt mixtures without compromising the performance of the mixture. ANOVA results showed that the warm additive had meaningful effects on MR, ITS, and FE; the same was true for the effects of the warm additive-binder type interaction.
\end{abstract}

\section{Introduction}

Rutting and fatigue cracking are two primary distresses of asphalt pavements. Recently, numerous pavement researchers have tried to improve the asphalt mixtures' performance characteristics at high- and low-performance temperatures. Moreover, several investigations have been implemented to suggest an appropriate rheological factor to capture the bitumen's intermediate- and high-temperature properties precisely. The performance grading system introduces the rutting and fatigue factors to examine the high- temperature and intermediate-temperature characteristics of modified and unmodified mixtures, respectively. Various studies have proved that these factors cannot calculate the bitumen's performance at rutting and its fatigue properties. These parameters exhibit a weak relation with mixture performance. Pavement researchers introduced advanced tests, such as MSCR and LAS tests, for a more precise evaluation of modified binders' rutting and fatigue behavior $[1,2]$. Several studies [1-10] concluded that it is crucial to improve binders with additives to better the mixtures' strength against mentioned distresses. A large number of 
additives involving crumb rubber (CR) [3, 4], styrene-butadiene rubber (SBR) [8], styrene-butadiene-styrene (SBS) [5], polypropylene (PP) [7], polyethylene (PE) [9], polyolefin elastomer (POE) [6], and nanomaterials [10] including nanocarbon fiber [11] and nanoclay were employed for enhancing bitumen's performance. Nevertheless, selecting an appropriate type of additive can differ from one country to another country because of countries' various geographical situations and existent capacities. When paving, specialists should consider factors beyond binders' proper performance, such as environmental compatibility, economic issues, and modifier production [12].

To produce a usual hot mix asphalt, a lot of energy is used and consequently air pollution can occur. The procedure to produce hot mix asphalts leads to the emission of several greenhouse gases, which in turn reduces the quality of air [13-18]. Warm mix asphalt (WMA) is introduced to reduce mixing compaction temperature of mixtures, which not only brings about a reduction of greenhouse gases and emissions but also decreases energy consumption by reducing mixing and compaction temperature by $30-50^{\circ} \mathrm{C}$. Based on the existing literatures [19-28], different types of technologies (chemical and organic additives) are used to make WMA. Several types of chemical additives were used to produce WMA additives such as emulsification agents, surfactants, antistripping additives, and aggregate coating enhancers. Utilization of oil is a very valuable choice among organic additives. In a study performed by Souza [29], utilization of mamona oil to produce WMA was evaluated. The research used $2-9 \%$ oil by weight of binder, which resulted in reduction of the mixing and compaction temperature by about $8^{\circ} \mathrm{C}$. In another study, $0-3 \%$ of mamona oil by weight of binder was used, and mixing and compaction was decreased by $5^{\circ} \mathrm{C}$.

Soybean is a grain type, which contains a lot of protein and is utilized by animals and humans. Soybean consists of $17-21 \%$ oil and $46 \%$ protein $[30,31]$. Accumulation of waste oil in the ground occupies a large space in the Earth. If after the frying process of soybean the by-product is not controlled properly, it leads to the pollution of the environment. Therefore, utilization of this waste oil can be adopted as a sustainable path to dealing with the risk. Several researches have previously been conducted to evaluate the effect of waste kitchen oil in reclaimed asphalt pavement. Additionally, several researches have been implemented where bio binders were used [32-34].

In a study performed by Zhang and $\mathrm{Li}$ [35], the effect of three warm mix agents on performance of binder with and without SBS was evaluated. Results revealed the softening point of binders containing SBS and three warm agents were higher than SBS modified binders. Based on results, the warm agent stiffens the SBS modified binder, and, as a result, the high temperature stability of specimens enhanced. Addition of zeolite leads to decrease in the resistance of SBS modified binders against low temperature. Hou et al. [36] evaluated the dynamic properties of warm foam modified mixtures in low-temperature areas. Results revealed that rising temperature and lowering temperature lead to increase in the dynamic modulus of warm foam modified binders. Shi et al. [37] evaluated the feasibility of utilization of warm additives to reduce the viscosity of high viscosity asphalt mixture. Surfactant warm additive was used in the current study. Results revealed that warm additive leads to decrease in the viscosity and softening point of binder while increasing the penetration degree and ductility of binder. Mixture containing 1.5\% warm additive has the best lowtemperature resistance. Tan et al. [38] evaluated the microstructural mechanical behavior of warm-mix reclaimed asphalt mixture. Results indicated that maximum compressive stress of virgin and RAP aggregate and cement mortar with interface is higher. Irfan et al. [39] investigated the fatigue and rutting performance of SMA mixture containing fiber. Results indicated that the mixture containing NMAS of $12.5 \mathrm{~mm}$ and $5.3 \%$ binder content has the best fatigue behavior.

The present study aims to assess the way new and waste soybean oil $(0 \%, 1.5 \%, 2.5 \%$, and $3.5 \%$ by weight of binder) play a role in reducing mixing and compaction temperatures. Moreover, binders rheological characteristics as well as SMA mixture mechanical characteristics were investigated. The modified binders' performance was assessed through implementing the physical tests (penetration grade, softening point) as well as rheological tests (rotational viscosity, DSR, MSCR, and LAS tests). Two-factor analysis of variance (ANOVA) was applied to analyze the data. Furthermore, asphalt mixtures' properties were investigated using (ITS), dynamic creep, resilient modulus (Mr), and FPB tests. Figure 1 indicates the research flowchart of the present study.

\section{Materials and Methods}

\subsection{Materials}

2.1.1. Aggregates. Telo quarry, in the north of Tehran Province, Iran, was defined as an aggregate source for this research. The aggregates' properties (physical as well as chemical) are presented in Tables 1 and 2, respectively. Nominal maximum aggregate size was $12.5 \mathrm{~mm}$. Figure 2 represents aggregate gradation used for fabricating different mixtures.

2.1.2. Bitumen. Two kinds of a virgin AC-60/70 and AC-85/ 100 binder have been applied. Physical properties of modified binders were investigated, and binder test outcomes are presented in Table 3.

2.1.3. Fiber. Usually, fiber is added to diminish binder drain down. The National Cooperative Highway Research Program (NCHRP) Report No. 425 was used to define the optimum content of asphalt binder [40]. The present paper proposes using $0.3 \%$ cellulose fiber to diminish the binder drain down as a better way. Table 4 depicts the fiber physical traits.

2.1.4. Soybean Oil. Soybean oil needed for the study was purchased from market. To gain waste oil, the new oil is fried 


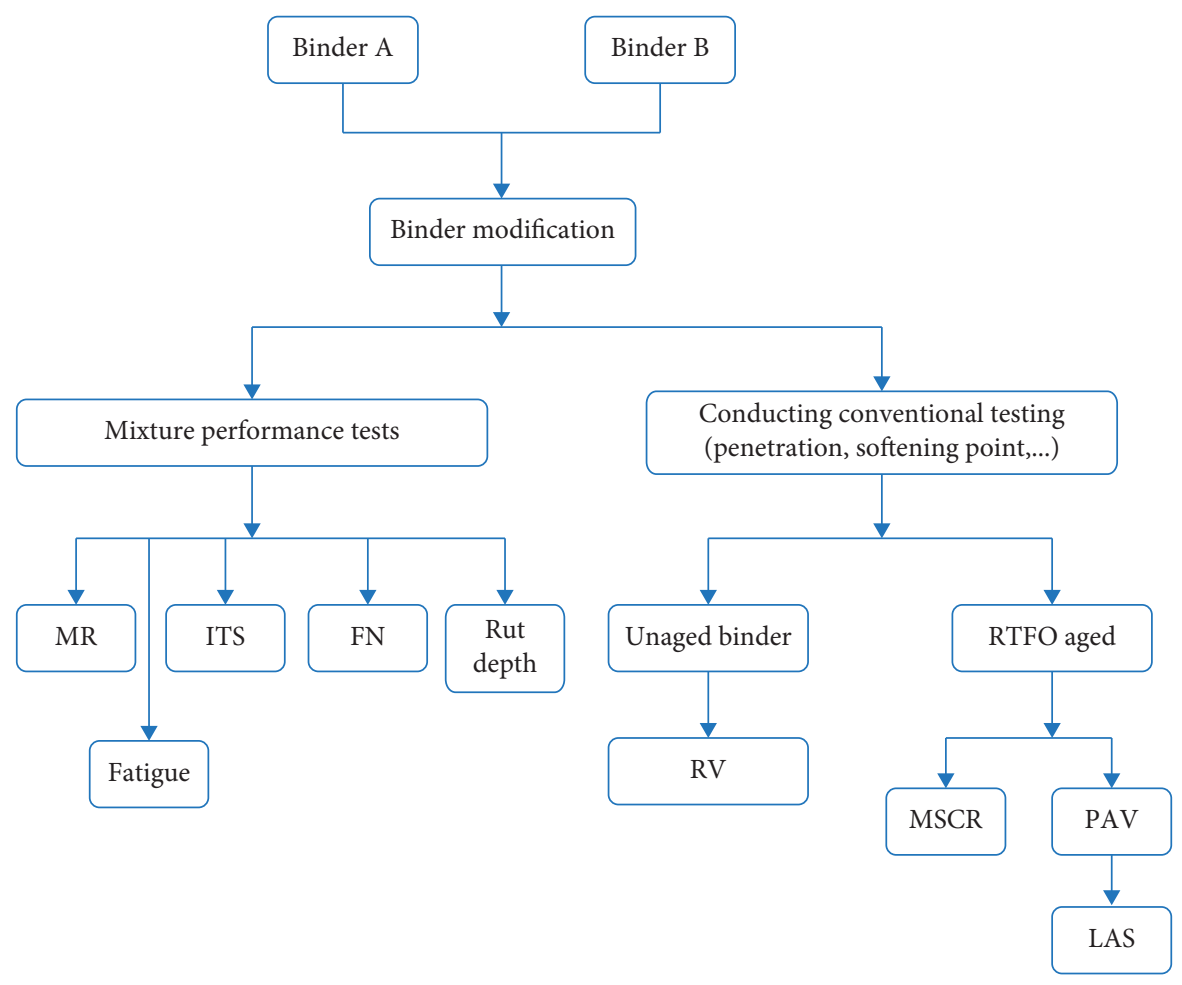

Figure 1: Flowchart of the research approach.

TABle 1: Physical properties of aggregates.

\begin{tabular}{lcc}
\hline Aggregate tests & Test method & Result \\
\hline Bulk specific gravity & ASTM C127 & 2.493 \\
Absorption coarse aggregate (\%) & ASTM C127 & 2.3 \\
Absorption fine aggregate (\%) & ASTM C128 & 4.1 \\
Los Angeles abrasion loss (\%) & AASHTO T96 & 22.3 \\
Two fractured faces (\%) & ASTM D5821 & 93 \\
\hline
\end{tabular}

TABle 2: Chemical properties of aggregates.

\begin{tabular}{lcccccccc}
\hline \multirow{2}{*}{ Type } & $\mathrm{SiO}_{2}$ & $\mathrm{CaO}$ & $\mathrm{Al}_{2} \mathrm{O}_{3}$ & $\mathrm{Fe}_{2} \mathrm{O}_{3}$ & $\mathrm{MgO}$ & $\mathrm{K}_{2} \mathrm{O}$ & $\mathrm{Na}_{2} \mathrm{O}$ & $\mathrm{MnO}$ \\
\hline $\begin{array}{l}\text { Lime } \\
\text { aggregate }\end{array}$ & 17.5 & 43 & 2.1 & 0.95 & 0.74 & 0.67 & 0.09 & 0.047 \\
\hline
\end{tabular}

and after that, the fried oil is collected. Then, the oil is decantated and filtered using paper filter. Table 5 shows chemical and physical properties of soybean oil.

Results indicated that acidic index of waste oil is 193\% higher than new oil. The literature suggests that water following through the frying process brings about a hydrolytic reaction, and, as a result, the free fatty acids and diglycerides are produced, and hence the acidic index increases. As such, the stiffness of bitumen increases, and the consistency of asphalt binder improves.

2.2. Sample Preparation. First, 600 gr of the base bitumen was heated to $170^{\circ} \mathrm{C}$. In order to prepare modified binders containing new oil, the new oil was obtained from a store in Tehran. The waste oil was produced through a frying process

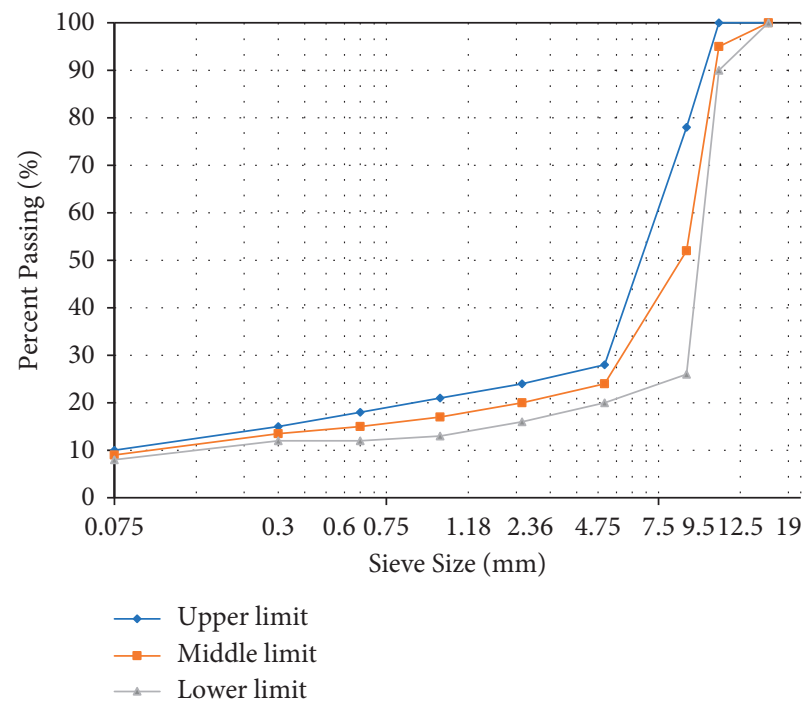

FIgURE 2: Aggregate gradation with NMAS of $12.5 \mathrm{~mm}$.

of several times of utilization and after that collected and used for research. To prepare a homogeneous modified binder, soybean oil $(1.5 \%, 2.5 \%$, and $3.5 \%)$ was gradually added to the binder and stirred for 20 minutes in a high shear mixer at $500 \mathrm{rpm}$. The mixing procedure was performed according to the existing literature [41, 42]. Several specimen containing differing amount of soybean oil $(1.5 \%$, $2.5 \%$, and $3.5 \%$ ) were produced. In the current study, the "Nsoy" and "Wsoy" stand for "new soybean" and "waste soybean," respectively. The NCHRP Report No. 425 was used for the outline of the mixture [43]. According to the 
TABle 3: Properties of the binder.

\begin{tabular}{lccc}
\hline Test (unit) & Method & Results 60-70 & Results 85-100 \\
\hline Penetration at $25^{\circ} \mathrm{C}, 100 \mathrm{gr}(0.1 \mathrm{~mm})$ & ASTM D5 & 66.5 & 46.6 \\
Softening point $\left({ }^{\circ} \mathrm{C}\right)$ & ASTM D36 & 100 & 45 \\
Ductility at $25^{\circ} \mathrm{C}(\mathrm{cm})$ & ASTM D113 & 302 & +100 \\
Flash point $\left({ }^{\circ} \mathrm{C}\right)$ & ASTM D92 & 320 & 270 \\
Fire point $\left({ }^{\circ} \mathrm{C}\right)$ & ASTM D70 & ASTM D70 & 1.043 \\
Specific gravity at $25^{\circ} \mathrm{C}\left(\mathrm{gr} / \mathrm{cm}^{3}\right)$ & & - \\
\hline
\end{tabular}

TABLE 4: Fibers' characteristics.

\begin{tabular}{lc}
\hline Properties & Value \\
\hline Cellulose fiber & \\
Cellulose content $(\%)$ & 80 \\
Bulk density $(\mathrm{g} / \mathrm{cm} 3)$ & 0.5 \\
$\mathrm{pH}$ value $(5 \mathrm{~g} / 100 \mathrm{ml})$ & 7.5 \\
Average fiber length $(\mathrm{mm})$ & 1.1 \\
Average fiber thickness $(\mathrm{mm})$ & 0.045 \\
\hline
\end{tabular}

TABLE 5: Soybean oil's physical and chemical behavior.

\begin{tabular}{lcc}
\hline Characteristics & New soybean oil & Waste soybean oil \\
\hline Acidic index $(\mathrm{mg} \mathrm{KOH} / \mathrm{g})$ & 0.73 & 2.19 \\
Iodine index $(\mathrm{mg} \mathrm{I} 2 / 100 \mathrm{~g})$ & 55.45 & 60.45 \\
Peroxide index $(\mathrm{meq} / \mathrm{kg})$ & 22.84 & 20.88 \\
Refraction index $\left(26^{\circ} \mathrm{C}\right)$ & 74.37 & 73.5 \\
Viscosity $\left(40^{\circ} \mathrm{C}\right)$ & 57.16 & 71.36 \\
\hline
\end{tabular}

mixture outline, an optimum binder achieved $7.5 \%$ binder content. For each of the unmodified and modified mixture types, three replicates were produced.

\section{Experimental Program}

3.1. Bitumen Tests. Softening point and penetration tests were performed for evaluating unmodified and modified binders' physical behavior. In addition, RV, BBR, and DSR tests were utilized for assessing various binders' rheological behavior [43].

3.1.1. MSCR Test. MSCR test was conducted for investigating modified asphalt mixtures rutting behavior according to AASHTO TP 70 "Multiple Stress Creep Recovery (MSCR) Test using a Dynamic Shear Rheometer (DSR)" [44]. Anton Paar DSR with its parallel-plate geometry loading device and a control and data acquisition system were utilized for conducting the MSCR test in the present study. Specimens were tested in replicates using a $25 \mathrm{~mm}$ disc and with $1 \mathrm{~mm}$ gap setting at temperature of $64^{\circ} \mathrm{C}$ and at a stress of 100 and $3200 \mathrm{~Pa}$ and aged through RTFO process. The tests were performed at the selected temperatures using a constant stress creep of 1-second duration and a relaxation period of 9 seconds, for ten cycles at each stress level.

3.1.2. LAS. LAS test was used for estimating unmodified and modified asphalt mixtures fatigue properties. The LAS test was performed on PAV aged samples. It was conducted in accordance with AASHTO TP 101-14 standards at $25^{\circ} \mathrm{C}$
[45]. The following equation was used for calculating different binders' fatigue life:

$$
N f=A(\gamma \max )^{B} \text {. }
$$

Here, the constants $A$ and $B$ are determined regarding the viscoelastic continuum damage theory (VECD).

\subsection{Asphalt Mixture Tests}

3.2.1. ITS Test. ITS test was used to assess the samples' moisture susceptibility according to the ASTM D6931-12 standard. Samples' ITS is calculated through the following [46-50]:

$$
I T S=\frac{2 P_{\max }}{\square D t} .
$$

Here, ITS stands for mixture's indirect tensile strength $(\mathrm{kPa}), D$ is the diameter of samples $(\mathrm{mm}), P_{\max }$ represents the maximum load $(\mathrm{kN})$, and $t$ represents the thickness of specimens $(\mathrm{mm})$.

One of the outcomes of ITS is FE, which can be calculated from the area under the load-deflection curve to failure load through the following [51]:

$$
\text { fracture energy }=\frac{\int_{0}^{\delta \max } P(\delta) \mathrm{d}(\delta)}{V} .
$$

Here, fracture energy is the total energy required to failure $\left(\mathrm{J} / \mathrm{m}^{2}\right), P$ is the applied load $(N), V$ shows the sample volume, and $d$ indicates deformation $(\mathrm{mm})$.

3.2.2. $M r$ Test. ASTM D 4123 standard was conducted to carry out the $\mathrm{Mr}$ test. The following equation is used to calculate the samples' resilient modulus [52]:

$$
M_{r}=\frac{P(v+0.2734)}{(\delta t)} .
$$

Here, $M r$ stands for resilient modulus (MPa), $t$ stands for specimen thickness $(\mathrm{mm}), P$ indicates load $(N)$, and $\delta$ indicates the horizontal deformation, which is recovered (mm).

3.2.3. Dynamic Creep Test. In this research, mixture samples' rutting resistance was examined regarding the US.NCHRP $9-19$ at $50^{\circ} \mathrm{C}$ on specimen that we preconditioned in room temperature. $450 \mathrm{kPa}$ stress level with $0.1 \mathrm{~s}$ loading and $0.9 \mathrm{~s}$ was applied to unmodified and modified mixtures samples. 
3.2.4. Wheel Tracking Test. The mixtures' resistance against rut depth was examined by the wheel track test at $60^{\circ} \mathrm{C}$ temperature according to AASHTO standard T-324 [53]. Specimens-which were mixed with the determined asphalt contents from mix design and fabricated by the rolling machine-were of dimensions $300 \mathrm{~mm} \square 300 \mathrm{~mm}$ in crosssectional area and $50 \mathrm{~mm}$ in height at an air void ratio of about 7\%, according to AASHTO-T324 [53]. The wheel tracking test was performed using $5.5 \mathrm{~kg} / \mathrm{cm} 2$ wheel pressure at $60^{\circ} \mathrm{C}$ temperature under dry condition. The wheel shall make 22 passes across the specimen per minute. Rut depth of asphalt mixtures was measured for 20,000 passes of $5.5 \mathrm{~kg} /$ $\mathrm{cm}^{2}$ loaded wheels at $60^{\circ} \mathrm{C}$.

3.2.5. FPB Test. For measuring mixtures' fatigue life, FPB test was applied regarding AASHTO T321-07 [54]. In the present paper, a constant strain test was applied to examine the samples' fatigue properties. The compacted slabs were cut to create fabricated beams with a $380 * 63.5 * 50 \mathrm{~mm}$ dimension according to AASHTO T321-07 standard. Figure 3 indicates the configuration of the test setup. Specimens' flexural stiffness was calculated utilizing the following [55-57]:

$$
\begin{aligned}
& \varepsilon=\frac{12 \delta h \times 10^{6}}{3\left(G_{0}^{2}-4 G_{1}^{2}\right)}, \\
& \sigma=\frac{G_{0} P}{B h^{2}}, \\
& S=\frac{1000 \sigma}{\varepsilon} .
\end{aligned}
$$

Here, $\varepsilon$ and $\delta$ represent maximum microstrain and maximum deformation in the center of the sample $(\mathrm{mm})$, respectively. $G_{1}$ shows the gauge's inner length $(118.5 \mathrm{~mm})$, $h$ indicates the gauge's outer length $(355.5 \mathrm{~mm}), h$ depicts the length of the sample $(\mathrm{mm}), P$ represents maximum tensile stress $(\mathrm{kPa}), B$ represents beam width $(\mathrm{mm}), P$ stands for the maximum load $(\mathrm{kN})$, and $S$ is flexural stiffness $(\mathrm{MPa})$.

The following equation is used to obtain the sample's fatigue life:

$$
N_{f}=a \varepsilon^{-b}
$$

Here, $N_{f}$ and $\varepsilon$ are specimen's fatigue life and microstrain level, respectively. $a$ and $b$ are constants.

\section{Results and Discussion}

\subsection{Binder Tests' Results}

4.1.1. Physical and Rheological Test Results. Figures 4 and 5 represent the physical bitumen tests' results for original and soybean modified bitumens. According to the outcomes, adding soybean decreases the softening point and increases the penetration. An increase in soybean percentage leads to an in increase in samples' penetration up to $2.5 \%$, while the softening point of the samples decreases. Several researches, which added vegetable oil to base binder, revealed that by addition of vegetable oil, the ratio of asphaltenes to maltenes decreases, which leads to an increase in the penetration degree of the binder [18]. By increasing the percentage of oil, the softening point of the binder decreases, which results in decreasing the consistency of the binder. It can be concluded that by the addition of oil to the binder, the binder's sensitivity to temperature increases. Based on the softening point results, among modified binders, binders containing 1.5\% waste soybean oil performed the best and hence can be used in the field. This is because it keeps the temperature within the average $50^{\circ}$, which is higher than the average temperature of Iran. Based on previous research results, the acidic index of waste soybean oil is approximately two times greater than the new soybean oil. By increasing the acid, the hydrolytic reactions improve and lead to the production of free fatty acids and diglycerides based on the presence of water and elevated temperatures while frying [58]. Increment in acid leads to the breaking of the triglyceride's chains, the chief ingredient of oil is freed, and the oxidation of oil will occur [58]. The mentioned reaction leads to a change in the rheological behavior of bitumen and enhances the stiffness of the binder. Consequently, the rutting performance of bitumen is enhanced. As a result, the penetration results of binder modified by waste oil are lower than new oil.

As Figure 6 shows, adding soybean decreases the original binder's viscosity. Regarding viscosity test results, it was observed that viscosity decreases by adding soybean percentage. The viscosity results of binders modified by waste oil did not show any significant difference in contrast with binders containing new oil, which indicates that the waste oil can be used instead of new oil in modification. It can be inferred from the results that by increasing the percentage of oil, the mixing and compaction temperatures decrease. Based on the results, an addition of $3.5 \%$ oil leads to a decrease of the mixing and compaction temperature down to about $8.1^{\circ} \mathrm{C}$ for mixtures containing new oil and to $7.2^{\circ} \mathrm{C}$ for mixtures containing waste oil. Table 6 shows the mixing and compaction temperature of mixtures.

Viscosity-temperature curves are usually obtained for evaluating the susceptibility of temperature as well as measuring the mixtures' mixing temperature. Figure 7 represents the outcomes of viscosity variations versus temperature for new and waste soybean oil modified bitumens. The test outcomes showed a decrease in binders' viscosity when utilizing oil, which leads to a decrease in the stiffness of binders. In addition, according to the outcomes, adding waste oil to original binder decreases the viscosity. Moreover, to investigate the susceptibility of binder versus temperature, the Viscosity Temperature Susceptibility (VTS) values were obtained. The findings presented in Table 7 show a reduction in the VTS amount of base bitumen when using soybean oil. Furthermore, the VTS results presented in Table 7 indicate a reduction in the VTS at $90-160^{\circ} \mathrm{C}$ by soybean oil application.

4.1.2. MSCR Test Results. Rutting behaviors of the binder were evaluated through the MSCR test. Two of the MSCR test results include Jnr factor, and percent recovery $(\% R)$ was 

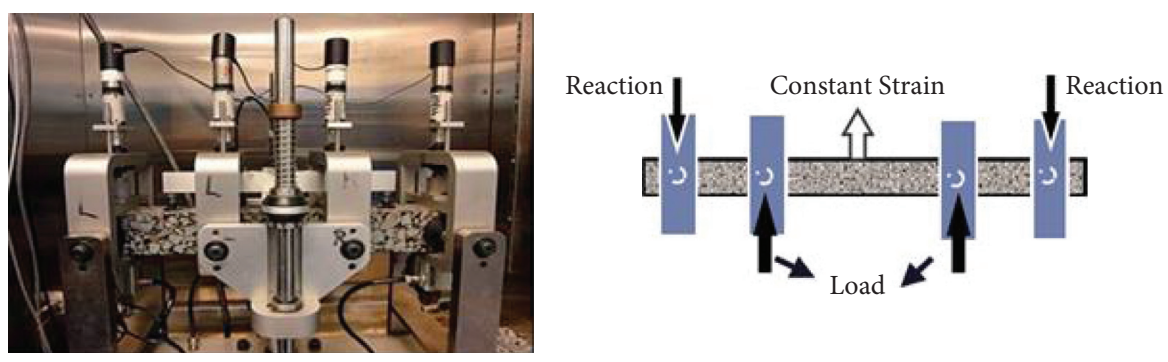

FIGURE 3: Schematic of the FPB fatigue test.

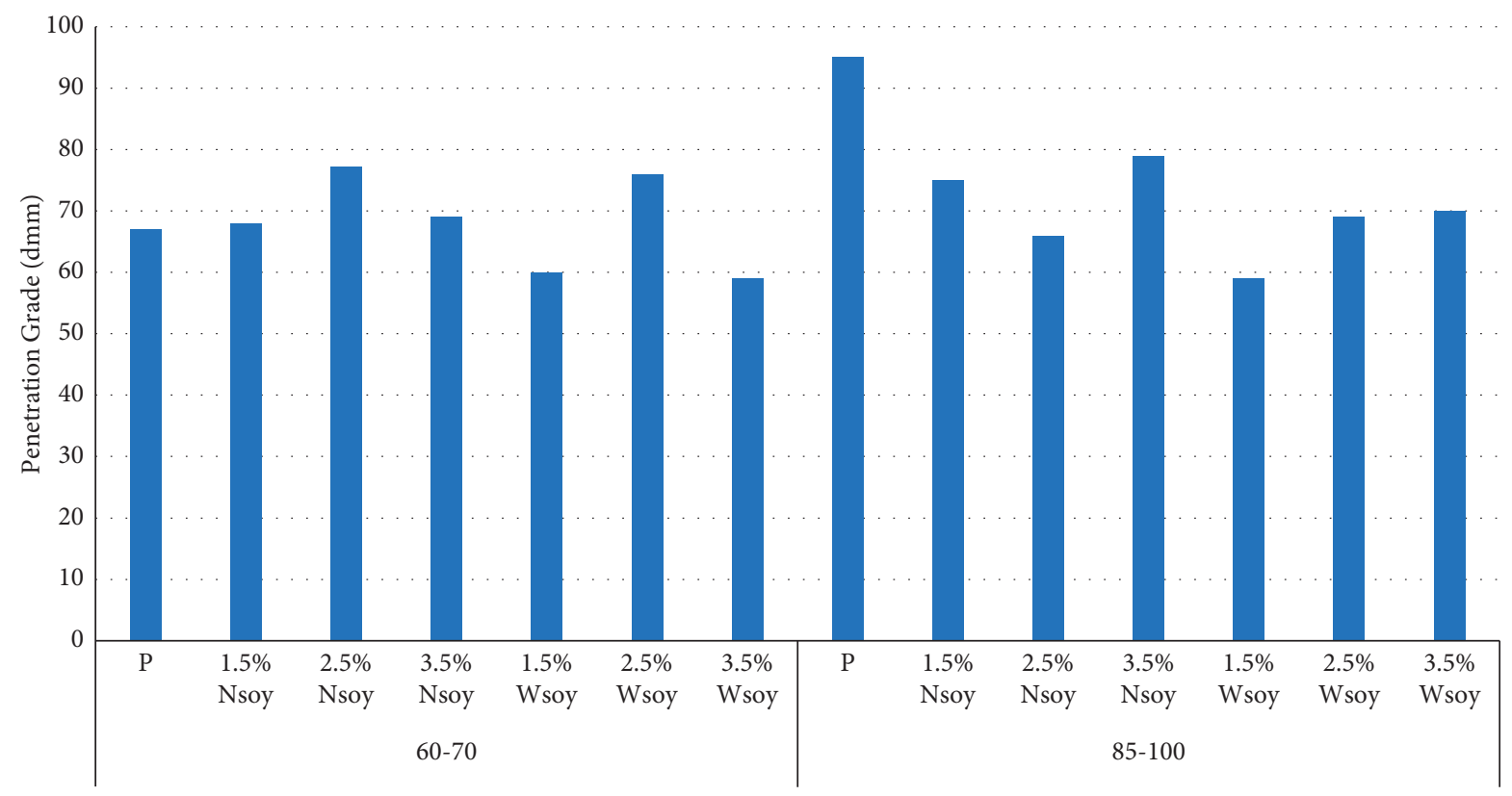

Modified Binders

FIgURE 4: Penetration results of unmodified and modified asphalt mixtures.

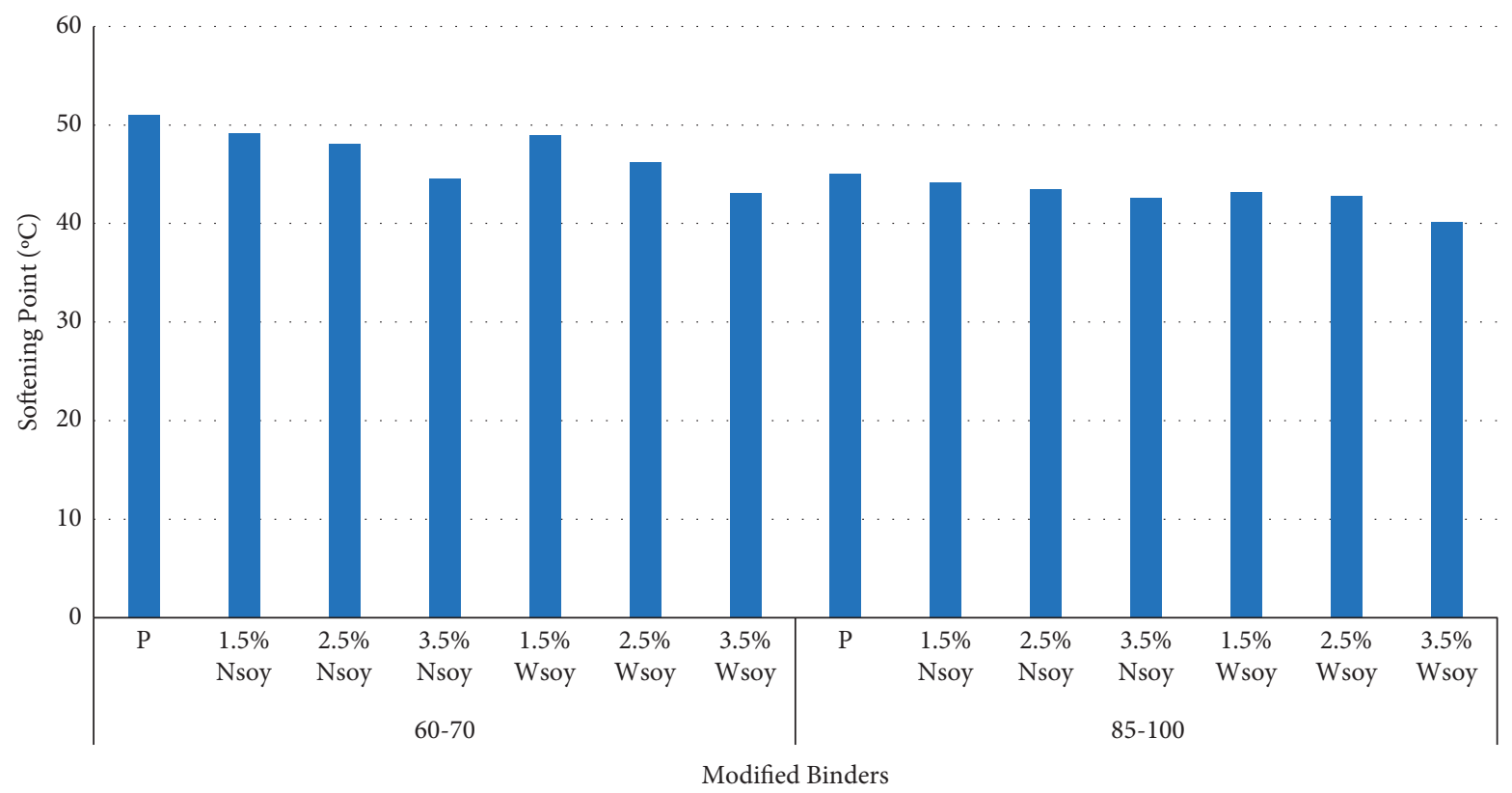

FIGURE 5: Softening point of unmodified and modified asphalt mixtures. 


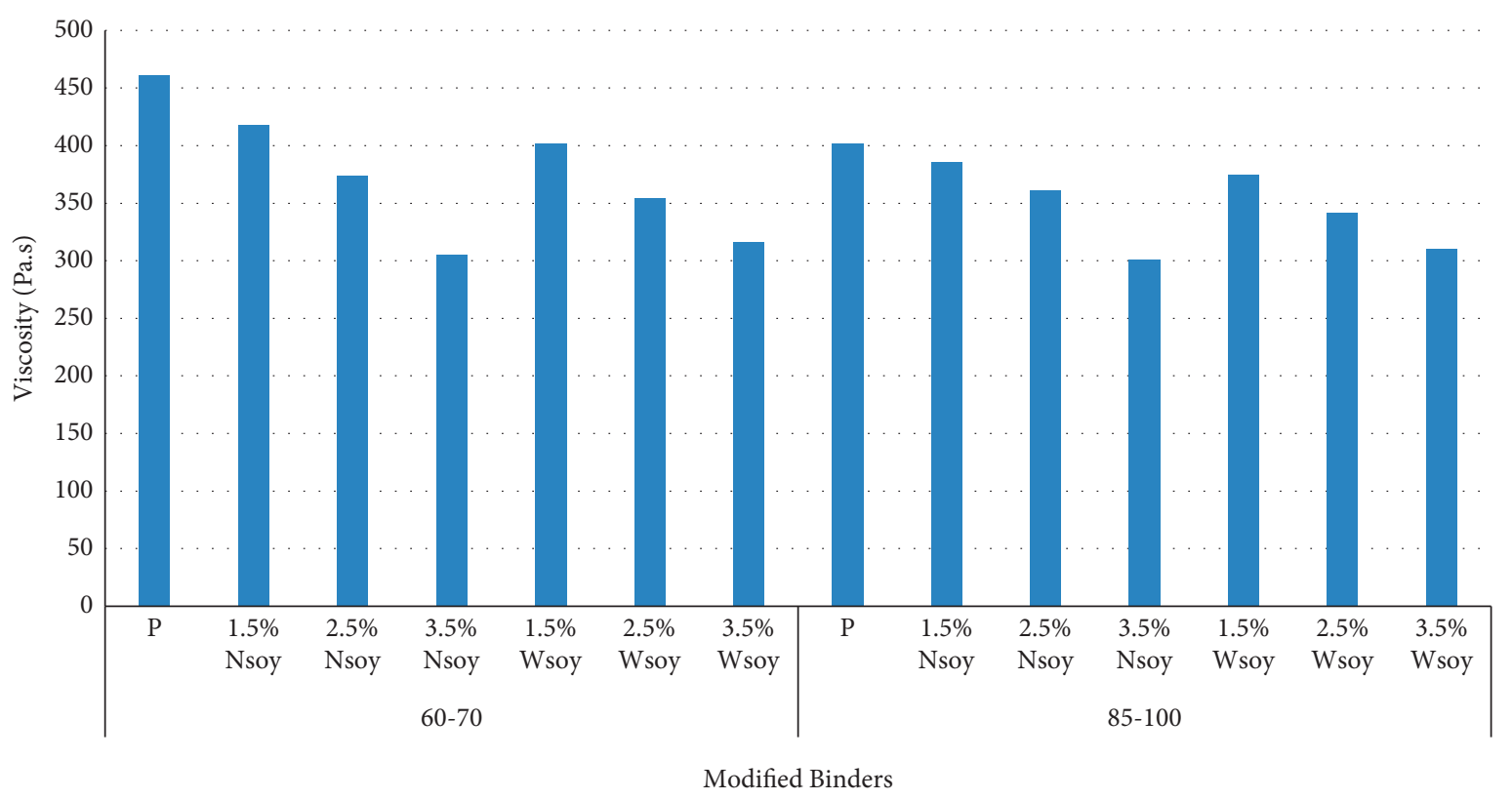

Figure 6: Rotational viscosity of unmodified and modified mixtures.

TABLE 6: Mixing and compaction temperatures of mixtures.

\begin{tabular}{cccc}
\hline \multicolumn{2}{c}{ Binder type } & $\begin{array}{c}\text { Mixing } \\
\text { temperature }\end{array}$ & $\begin{array}{c}\text { Compaction } \\
\text { temperature }\end{array}$ \\
\hline \multirow{6}{*}{$60-70$} & 158.1 & 138.1 \\
& P & 150 & 131 \\
& $2.5 \%$ Nsoy & 149 & 130 \\
& $3.5 \%$ Nsoy & 147 & 129 \\
& $1.5 \%$ Wsoy & 150.9 & 131.9 \\
& $2.5 \%$ Wsoy & 149.5 & 132 \\
& $3.5 \%$ Wsoy & 148.6 & 131.6 \\
& P & 153 & 135 \\
$85-100$ & $1.5 \%$ Nsoy & 145 & 128 \\
& $2.5 \%$ Nsoy & 143.5 & 127 \\
& $3.5 \%$ Nsoy & 142.4 & 126 \\
& $1.5 \%$ Wsoy & 146 & 129.5 \\
$2.5 \%$ Wsoy & 144.5 & 129 \\
\hline
\end{tabular}

calculated at 100 and $3200 \mathrm{~Pa}$ stress levels at $64^{\circ} \mathrm{C}$. The binders' Jnr and \% $\mathrm{R}$ results at $64^{\circ} \mathrm{C}$ are demonstrated in Table 8, respectively. In general, the results revealed that-ignoring the levels of stress-using soybean oil increases the value of pure binder Jnr, indicating the production of a binder that enjoys lower rutting resistance with soybean oil modification. When the amount of soybean oil goes higher, the rutting performance worsens. The results suggest that the utilization of soybean decreases the rigidity of binders, and, as a result, the elasticity of binders increases. This can help the binder to resist against fatigue cracking. The highest rutting resistance belongs to binders modified with $3.5 \%$ oil. Additionally, the $2.5 \%$ soybean modified binder has the highest Jnr as compared to other modified binders. In general, the results revealed that regardless of the levels of stress, adding soybean to bitumen increases the value of pure binder Jnr indicating lower rutting resistance of binders modified with additives. The Jnr results of binders containing waste oil do not show any significant difference compared to binders with new oil. These results are in consistence with the penetration, softening, and viscosity of binders. Based on previous research results, the acidic index of waste soybean oil is approximately two times greater than the new soybean oil. By increasing the acid, the hydrolytic reactions improve and lead to producing free fatty acids and diglycerides based on the presence of water and elevated temperatures while frying [48]. Increment in acid leads to the breaking of the triglycerides chains, and the chief ingredient of oil is freed and the oxidation of oil will occur [49]. The mentioned reaction leads to a change in the rheological behavior of bitumen and enhances the stiffness of binders. Consequently, the rutting performance of bitumen is enhanced.

As the results of $\% \mathrm{R}$ show, the $\% \mathrm{R}$ of binders containing $1.5 \%$ and $2.5 \%$ of soybean oil for new and waste types is higher than $3.5 \%$ in binders modified by $3.5 \%$ new oil, while the results of $\% \mathrm{R}$ are lower than in the waste oil type. Binders having lower values of $\% \mathrm{R}$ show lower resistance against fatigue cracking and rutting.

The percentage of difference in nonrecoverable creep compliance (Jnr-diff) was proposed to examine the bitumens' sensitivity against changes of binders' stress levels when increasing from $100 \mathrm{~Pa}$ to $3200 \mathrm{~Pa}$. The (Jnr-diff) parameter was constrained to $75 \%$. If the (Jnr-diff) goes higher than $75 \%$, it indicates the stress sensitivity of the binder. According to the findings presented in Table 8, the (Jnr-diff) value of modified bitumens is less than $75 \%$.

4.1.3. LAS Results. Tables 9 and 10 present LAS test results. Results indicate that binders' modification using additives reduces the high-stress levels' shear stress. Table 9 indicates 


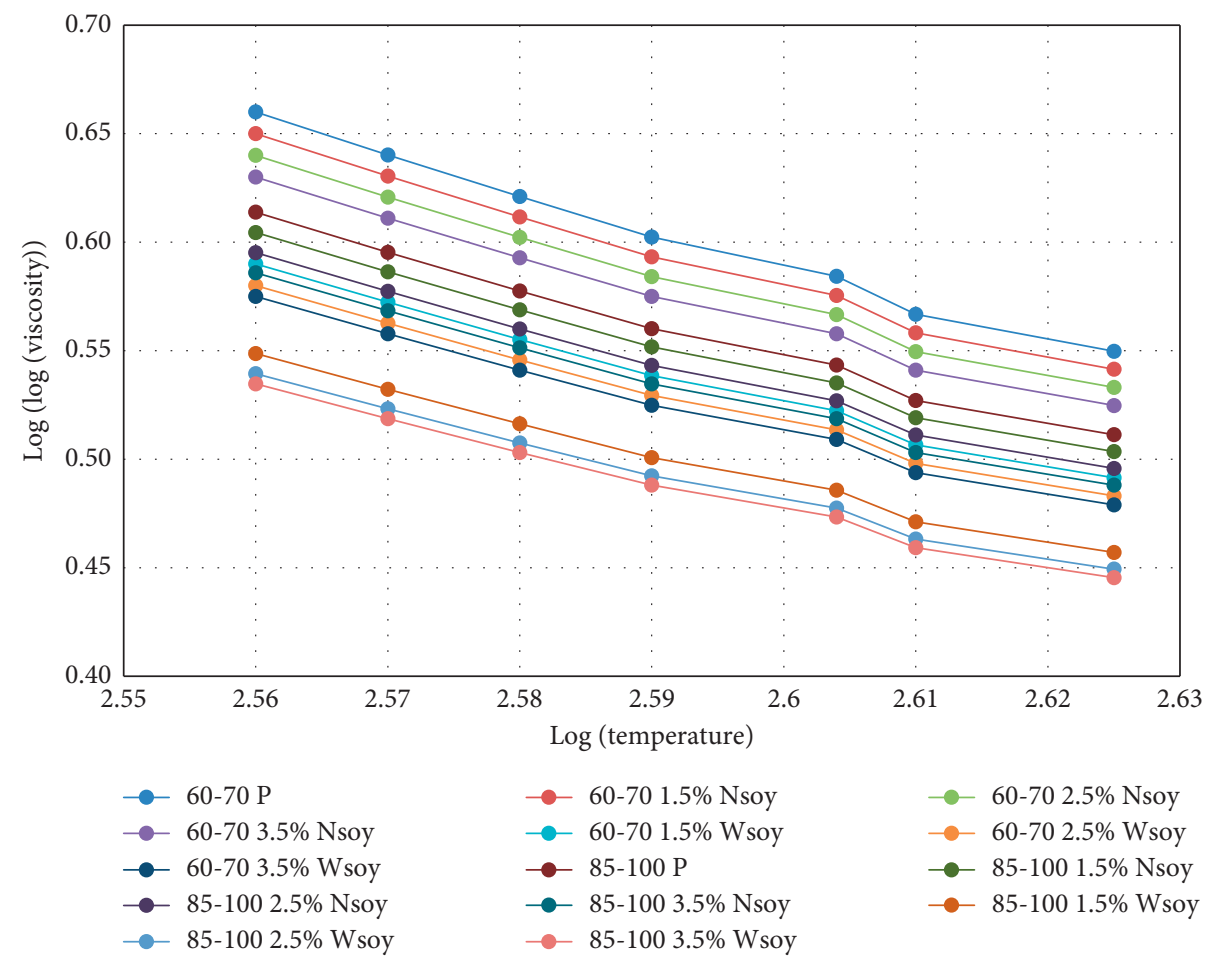

FIgURE 7: Viscosity Temperature Susceptibility (VTS) of unmodified and modified mixtures.

TABLE 7: VTS of unmodified and modified binders.

\begin{tabular}{ccccccc}
\hline \multicolumn{2}{c}{ Additive } & \multicolumn{5}{c}{ Log temperature } \\
& & 110 & 130 & 150 & 160 & 170 \\
\hline \multirow{6}{*}{ P } & 4.15 & 3.58 & 3.1 & 2.65 & 2.41 \\
& $1.5 \%$ Nsoy & 4.1 & 3.51 & 3.04 & 2.61 & 2.38 \\
& $2.5 \%$ Nsoy & 4.08 & 3.49 & 3 & 2.58 & 2.34 \\
& $3.5 \%$ Nsoy & 4.06 & 3.46 & 2.99 & 2.56 & 2.32 \\
& $1.5 \%$ Wsoy & 4.12 & 3.4 & 2.95 & 2.51 & 2.3 \\
& 2.5\% Wsoy & 4.05 & 3.31 & 2.93 & 2.45 & 2.2 \\
& 3.5\% Wsoy & 3.92 & 3.22 & 2.82 & 2.43 & 2.16 \\
& P & 3.86 & 3.33 & 2.88 & 2.46 & 2.24 \\
& $1.5 \%$ Nsoy & 3.81 & 3.26 & 2.83 & 2.43 & 2.21 \\
& $2.5 \%$ Nsoy & 3.79 & 3.25 & 2.79 & 2.40 & 2.18 \\
& $3.5 \%$ Nsoy & 3.78 & 3.22 & 2.78 & 2.38 & 2.16 \\
& $1.5 \%$ Wsoy & 3.83 & 3.16 & 2.74 & 2.33 & 2.14 \\
& $2.5 \%$ Wsoy & 3.77 & 3.08 & 2.72 & 2.28 & 2.05 \\
& $3.5 \%$ Wsoy & 3.65 & 2.99 & 2.62 & 2.26 & 2.01 \\
\hline
\end{tabular}

the bitumen fatigue life. The bitumen's fatigue life at one low as well as one high strain levels is presented in Table 9. The results demonstrated that adding soybean oil up to $2.5 \%$ enhances the pure binder fatigue life at low strain levels probably because of an enhancement in the flexibility of binder due to the utilization of soybean. Based on the results, fatigue life of binders containing $1.5 \%$ and $2.5 \%$ new soybean oil has higher values than original binders, and the sample containing $3.5 \%$ soybean has lower fatigue life. It can be inferred from the results that samples containing waste oil have lower fatigue life than samples containing new oil except by $3.5 \%$ one. By increasing the temperature and percentages of oil, the rigidity of mixtures decreases. The
$2.5 \%$ oil has the highest decrease. Based on the existing literature, binders with lower stiffens have better fatigue life, which is attributed to the lower thermal stress of the bitumen $[59,60]$.

Table 10 depicts the VECD results of the binder. By increasing the percentage of the additives, the $C 1$ and $C 2$ coefficients decrease and increase, respectively. Results revealed that using modified binders at low levels of strain is better.

Binders show better fatigue behavior at lower levels of strain. As in high strain levels, more deformation happens. The binder that was modified does not deform due to its high level of viscosity. Therefore, bitumen having less viscosity shows greater fatigue life compared to modified bitumens having greater viscosity $[51,52]$.

\subsection{Mixture Test Results}

4.2.1. Results of $M r$ Test. Figure 8 exhibits asphalt mixtures specimens' $M r$ values. As presented in Figure 8, soybean oil decreases the mixtures' resilient modulus. Utilizing 3.5\% oil modified mixtures decreases $M r$ value about $15 \%$, probably because of decreasing the specimens' stiffness by adding soybean oil. This can be due to the decrease in the rigidity of the mixture via increasing the oil. The waste oil modified mixtures have higher rigidity than the new ones, and the $\mathrm{Mr}$ of mentioned mixtures are higher. Furthermore, mixtures containing waste soybean oil have lower $M r$ values than mixtures containing new oil. Mixtures with $2.5 \%$ oil have $5 \%$ lower MR value than the unmodified sample. Based on the 
TABLE 8: MSCR outcomes of unmodified and modified binders.

\begin{tabular}{|c|c|c|c|c|c|c|}
\hline \multicolumn{2}{|c|}{ Binder type } & \multirow{2}{*}{$\frac{\text { Jnr @100 Pa }}{1.5}$} & \multirow{2}{*}{$\frac{\text { Recovery } 100 \mathrm{~Pa}}{28}$} & \multirow{2}{*}{$\frac{\text { Jnr@ } @ 3200 \mathrm{~Pa}}{2.4}$} & \multirow{2}{*}{$\frac{\text { Recovery } 3200 \mathrm{~Pa}}{2}$} & \multirow{2}{*}{$\begin{array}{c}\text { Jnr-diff } \\
37.5\end{array}$} \\
\hline \multirow{7}{*}{$60-70$} & $\mathrm{P}$ & & & & & \\
\hline & $1.5 \%$ Nsoy & 2.63 & 12 & 3.419 & 0.7 & 27 \\
\hline & $2.5 \%$ Nsoy & 2.67 & 18 & 3.471 & 0.5 & 34 \\
\hline & $3.5 \%$ Nsoy & 2.3 & 10 & 2.99 & 2 & 20 \\
\hline & $1.5 \%$ Wsoy & 2.53 & 9 & 3.289 & 3 & 16 \\
\hline & $2.5 \%$ Wsoy & 2.91 & 15 & 3.9 & 4.1 & 24 \\
\hline & $3.5 \%$ Wsoy & 2.1 & 19 & 2.34 & 1.3 & 34 \\
\hline \multirow{7}{*}{$85-100$} & $\mathrm{P}$ & 2.68 & 41 & 3.484 & 3 & 32 \\
\hline & $1.5 \%$ Nsoy & 2.86 & 23 & 3.718 & 0.98 & 36 \\
\hline & $2.5 \%$ Nsoy & 2.97 & 30 & 3.861 & 0.7 & 41 \\
\hline & $3.5 \%$ Nsoy & 2.63 & 18 & 3.419 & 3.87 & 30 \\
\hline & $1.5 \%$ Wsoy & 2.74 & 15 & 3.562 & 4 & 16 \\
\hline & $2.5 \%$ Wsoy & 3.2 & 19 & 4.16 & 5.2 & 12 \\
\hline & $3.5 \%$ Wsoy & 2 & 25 & 2.6 & 2.4 & 25 \\
\hline
\end{tabular}

Table 9: Fatigue lives of unmodified and modified binders.

\begin{tabular}{|c|c|c|c|}
\hline \multicolumn{2}{|c|}{ Binder type } & \multirow{2}{*}{$\frac{2.5 \% \mathrm{Nf}}{2450}$} & \multirow{2}{*}{$\frac{5 \% \mathrm{Nf}}{1000}$} \\
\hline \multirow{7}{*}{$60-70$} & $\mathrm{P}$ & & \\
\hline & $1.5 \%$ Nsoy & 2600 & 1045 \\
\hline & $2.5 \%$ Nsoy & 2890 & 1200 \\
\hline & $3.5 \%$ Nsoy & 2400 & 934 \\
\hline & $1.5 \%$ Wsoy & 2300 & 840 \\
\hline & $2.5 \%$ Wsoy & 2450 & 750 \\
\hline & $3.5 \%$ Wsoy & 2500 & 1054 \\
\hline \multirow{7}{*}{$85-100$} & $\mathrm{P}$ & 3185 & 1300 \\
\hline & $1.5 \%$ Nsoy & 3380 & 1358.5 \\
\hline & $2.5 \%$ Nsoy & 3757 & 1560 \\
\hline & $3.5 \%$ Nsoy & 3120 & 1214.2 \\
\hline & $1.5 \%$ Wsoy & 2990 & 1092 \\
\hline & $2.5 \%$ Wsoy & 3185 & 975 \\
\hline & $3.5 \%$ Wsoy & 3250 & 1370.2 \\
\hline
\end{tabular}

TABle 10: VECD coefficients.

\begin{tabular}{|c|c|c|c|c|}
\hline \multicolumn{2}{|c|}{ Binder type } & $C_{0}$ & $C_{1}$ & $C_{2}$ \\
\hline \multirow{7}{*}{$60-70$} & $\mathrm{P}$ & 1 & 0.09960012 & 0.46049347 \\
\hline & $1.5 \%$ Nsoy & 1 & 0.08554175 & 0.44672221 \\
\hline & $2.5 \%$ Nsoy & 1 & 0.08745118 & 0.45950058 \\
\hline & $3.5 \%$ Nsoy & 1 & 0.06196276 & 0.55619817 \\
\hline & $1.5 \%$ Wsoy & 1 & 0.069 & 0.546 \\
\hline & $2.5 \%$ Wsoy & 1 & 0.06296276 & 0.55719817 \\
\hline & $3.5 \%$ Wsoy & 1 & 0.0638743 & 0.5584329 \\
\hline \multirow{7}{*}{$85-100$} & $\mathrm{P}$ & 1 & 0.10458013 & 0.48351814 \\
\hline & $1.5 \%$ Nsoy & 1 & 0.08981884 & 0.46905832 \\
\hline & $2.5 \%$ Nsoy & 1 & 0.09182374 & 0.48247561 \\
\hline & $3.5 \%$ Nsoy & 1 & 0.06506089 & 0.58400807 \\
\hline & $1.5 \%$ Wsoy & 1 & 0.07245 & 0.5733 \\
\hline & $2.5 \%$ Wsoy & 1 & 0.06611089 & 0.58505807 \\
\hline & $3.5 \%$ Wsoy & 1 & 0.06706802 & 0.58635455 \\
\hline
\end{tabular}

results, mixtures containing 85/100 bitumen have lower $\mathrm{Mr}$ in comparison with mixtures containing 60/70 binder.

4.2.2. ITS Test. Figure 9 presents specimens' ITS values. The results showed that soybean oil modified mixtures possess lower ITS compared to unmodified samples. Findings show a decrease in the ITS values when increasing the oil content. Moreover, mixtures containing waste oil have lower ITS values than mixtures containing new oil. This can be attributed to the decrease in the rigidity of mixtures due to increasing oil. The waste oil modified mixtures have higher rigidity than new ones; the ITS of mentioned mixtures are higher. Regarding the findings, adding $1.5 \%$ oil to unmodified mixture decreases the value of ITS by around $6 \%$, while adding $3.5 \%$ oil results in a decrease in the ITS value by around $10 \%$. Based on the results, mixtures containing 85/ 100 bitumen have lower ITS in comparison with mixtures containing 60/70 binder.

4.2.3. FN Results. The specimens FN are presented in Figure 10. Greater values of FN indicate higher rutting resistance. According to the results presented in Figure 10, applying soybean oil increases the samples' permanent deformation because the stiffness of the mixture decreases, and this in turn decreases the strength of mixture versus permanent deformation. Moreover, adding oil contents decreases the samples' FN. The results demonstrate that the permanent deformation resistance improves when rising the percentage of oil. Besides, using soybean oil decreases the specimens' viscosity and stiffness, and this in turn decreases the rutting resistance. Results revealed that $1.5 \%$ oil modified mixtures possess FN 1.7 times lower than the virgin sample, whereas adding 3.5\% oil leads to decrease in the mixture modified with FN by $8 \%$. In addition, mixtures containing 60-70 bitumen have higher FN values than mixtures fabricated by $85 / 100$ binder.

4.2.4. Outcomes of the Wheel Tracking Test. Figure 11 represents specimens' rut depth. Results show that soybean oil increases specimens' rut depth. Soybean oil decreases the mixtures' stiffness. Additionally, using soybean oil decreases sample mixtures' rutting behavior, since as the soybean amount increases, the permanent deformation properties increase. The results also indicated a $2.4 \%$ increase in samples' permanent deformation when adding $1.5 \%$ soybean oil, while the use of $3.5 \%$ soybean oil leads to a $1.4 \%$ improvement in the mixture RD. Also, using soybean 


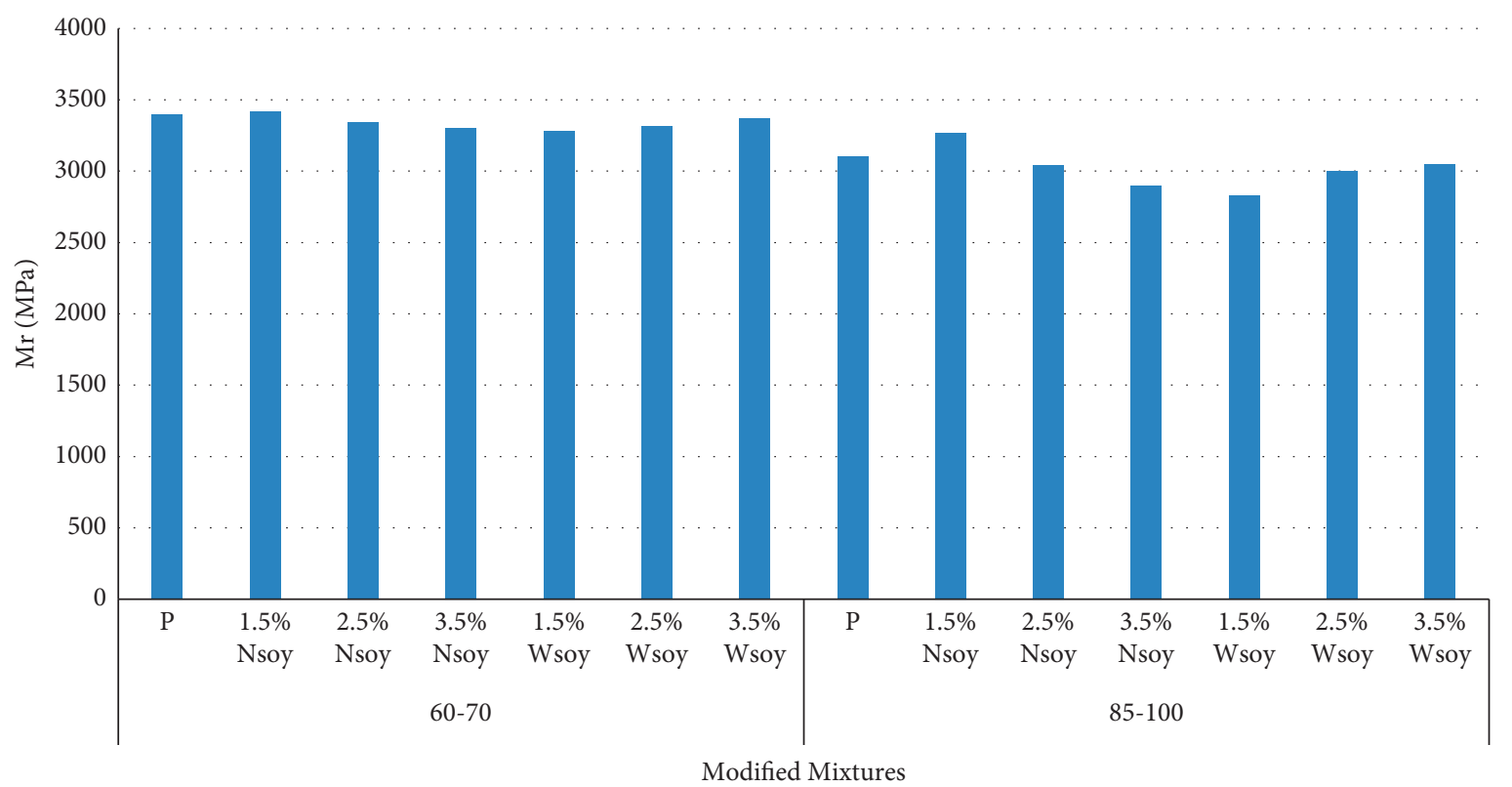

Figure 8: Results of unmodified and modified mixtures' resilient modulus.

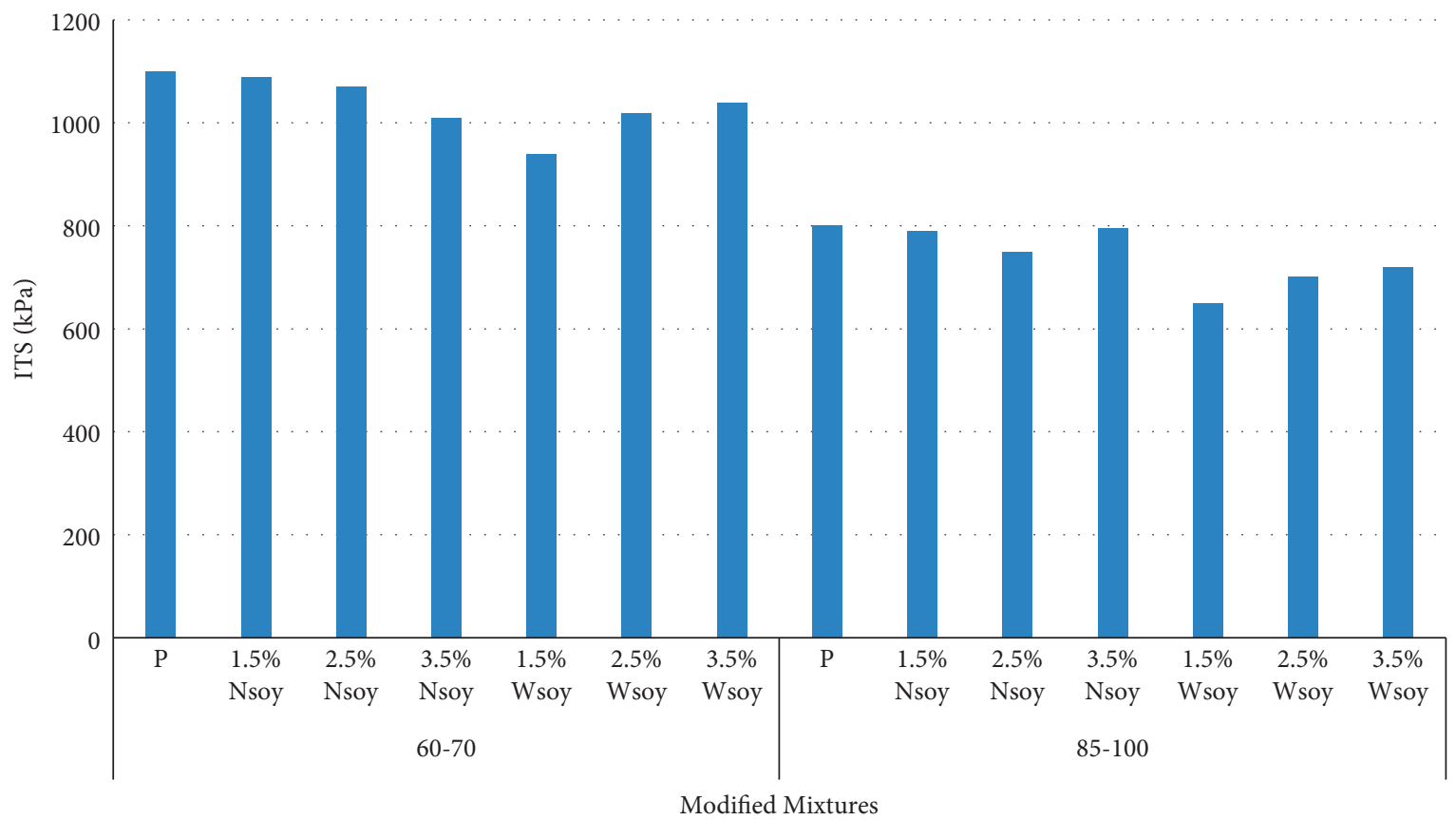

FIGURE 9: Unmodified and modified mixtures' ITS values.

oil decreases the specimens' viscosity and stiffness, and that in turn decreases the rutting resistance. Moreover, mixtures containing waste oil have higher RD than mixtures containing new oil. This is while mixtures fabricated with $85 / 100$ binder have higher $\mathrm{RD}$ than mixtures containing $60 / 70$ binder.
4.2.5. FPB Test Result. Figure 12 depicts the mixtures' fatigue life. Regarding the findings, adding soybean oil improves the mixtures' intermediate temperature performance. As the oil contents increase to up to $1.5 \%$, samples' fatigue lives increase and then decrease. The density values of mixtures' fracture energy (FE) are 


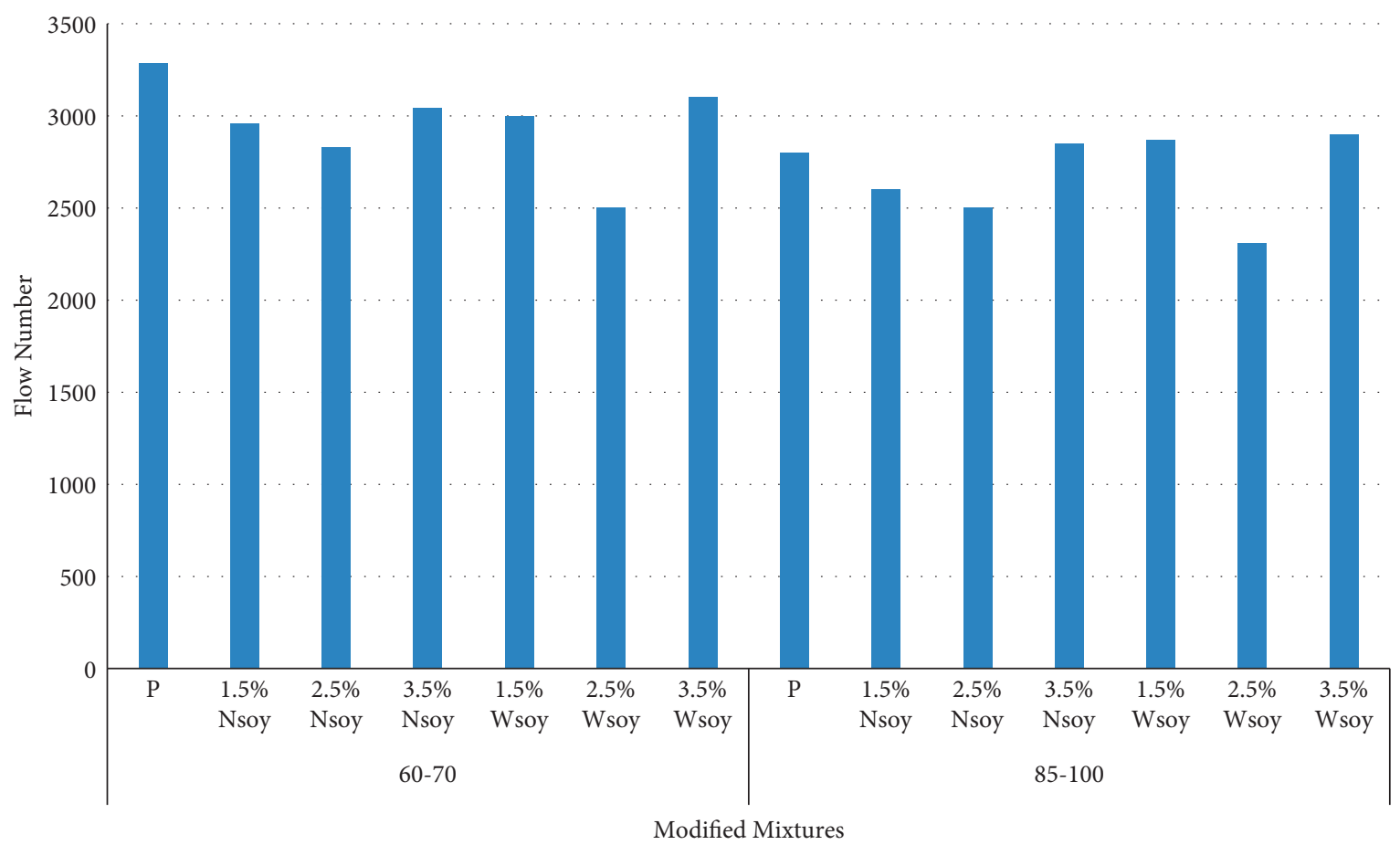

Figure 10: Unmodified and modified mixtures' flow number.

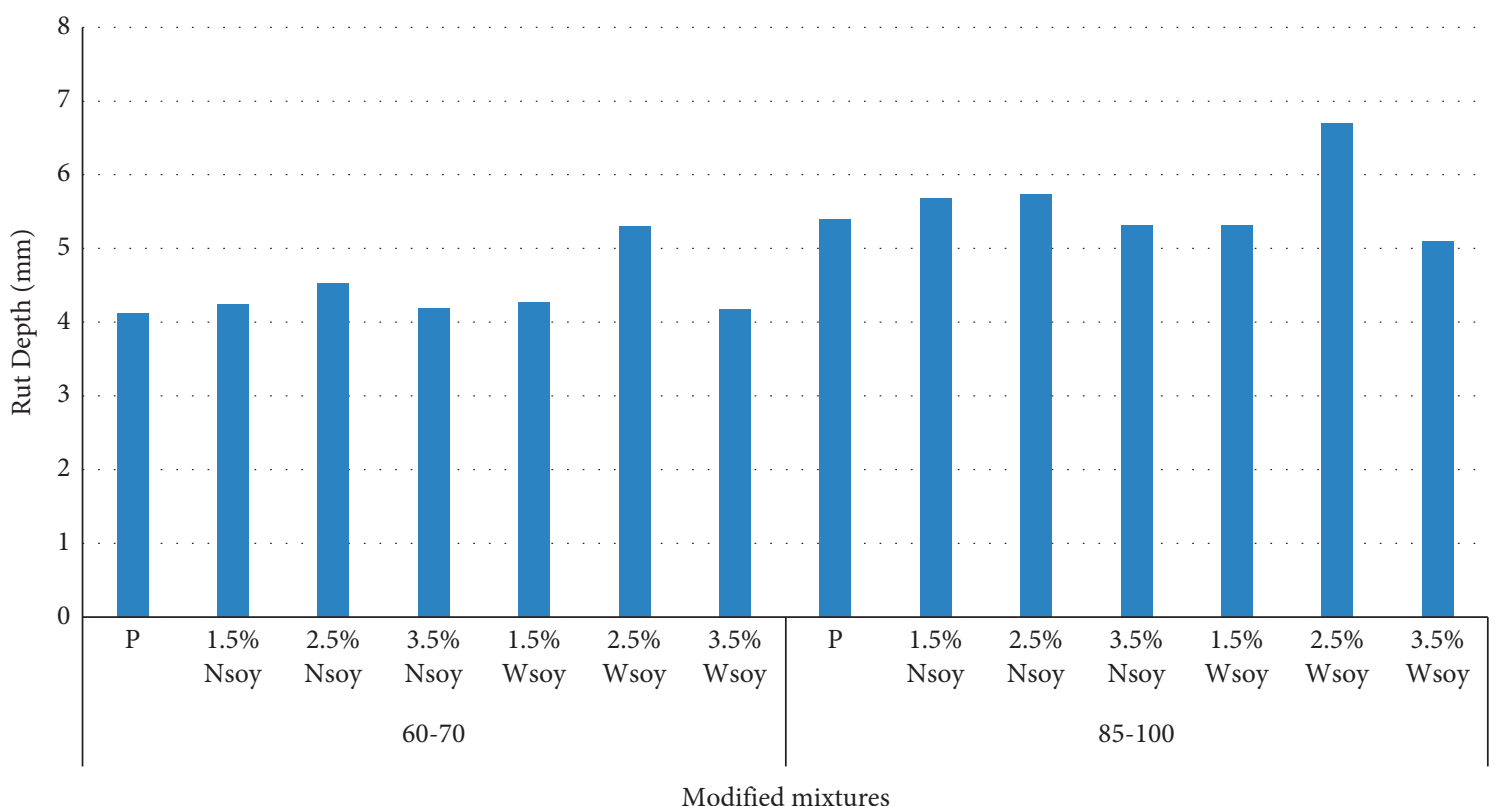

FIGURE 11: Unmodified and modified mixtures' rut depth.

indicated in Figure 13. As presented in this figure, adding soybean oil enhances the FE probably because using soybean oil enhances the samples' flexibility. Thus, the specimens' resistance is improved against cracking. Using soybean oil also enhances the FE of mixtures. The outcomes revealed that the FE results increases up to $1.5 \%$ and then decreases by increasing the oil content. Through increasing the temperature and percentages of oil, the rigidity of mixtures decreases. The $2.5 \%$ oil has the highest decrease.
Based on literature, binders with lower stiffness have better fatigue life, which is due to lower thermal stress of bitumen $[59,60]$.

4.2.6. Data Analysis Method. To analyze the data, this study made use of the two-factor (additive content and binder type) analysis of variance (ANOVA) (Tables $11-15)$, considering MR, ITS, flow number, and rut depth as dependent 


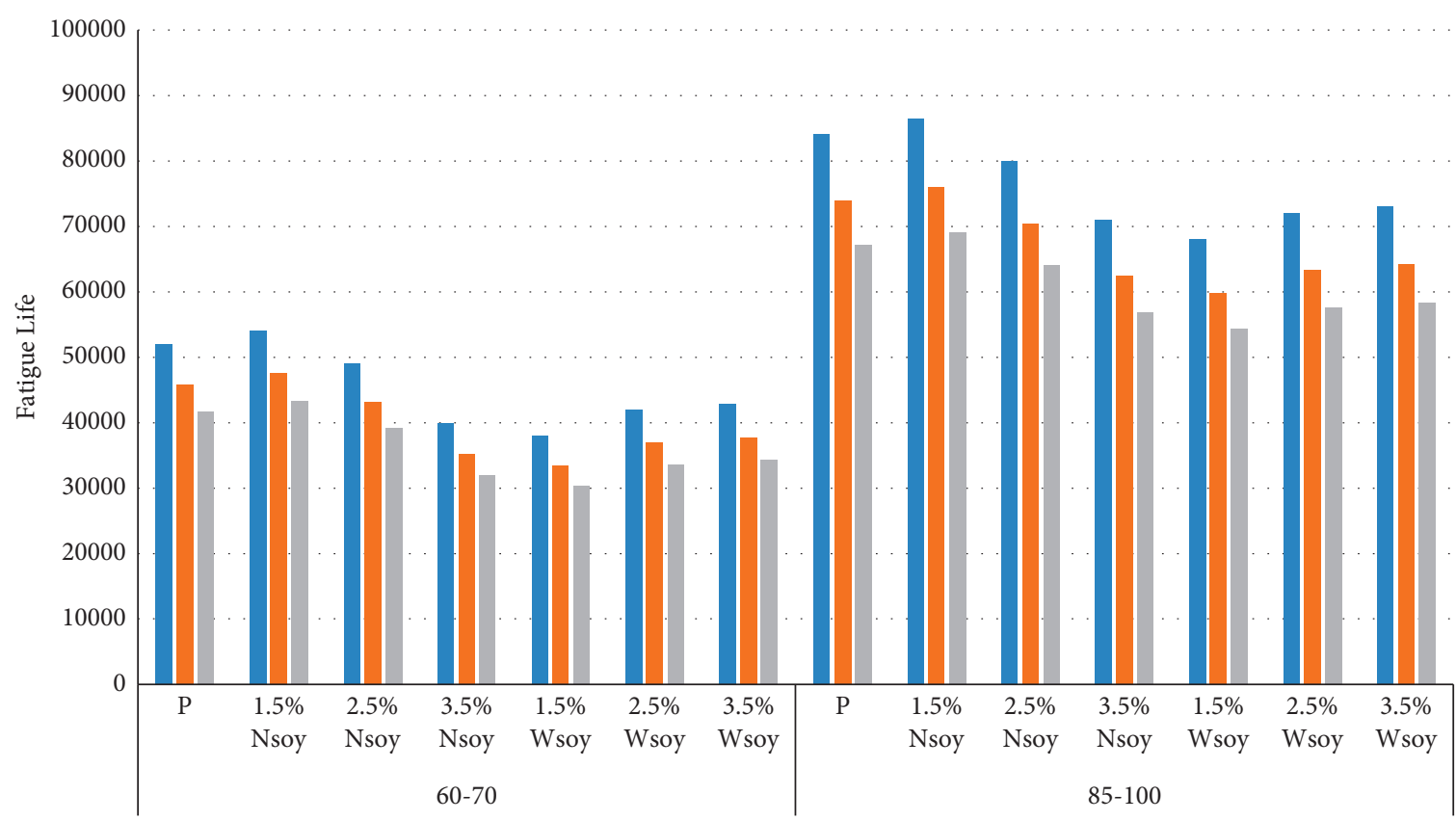

Modified Mixtures

600 Microstrain

800 Microstrain

1000 Microstrain

FIGURE 12: Unmodified and modified mixtures' fatigue lives.

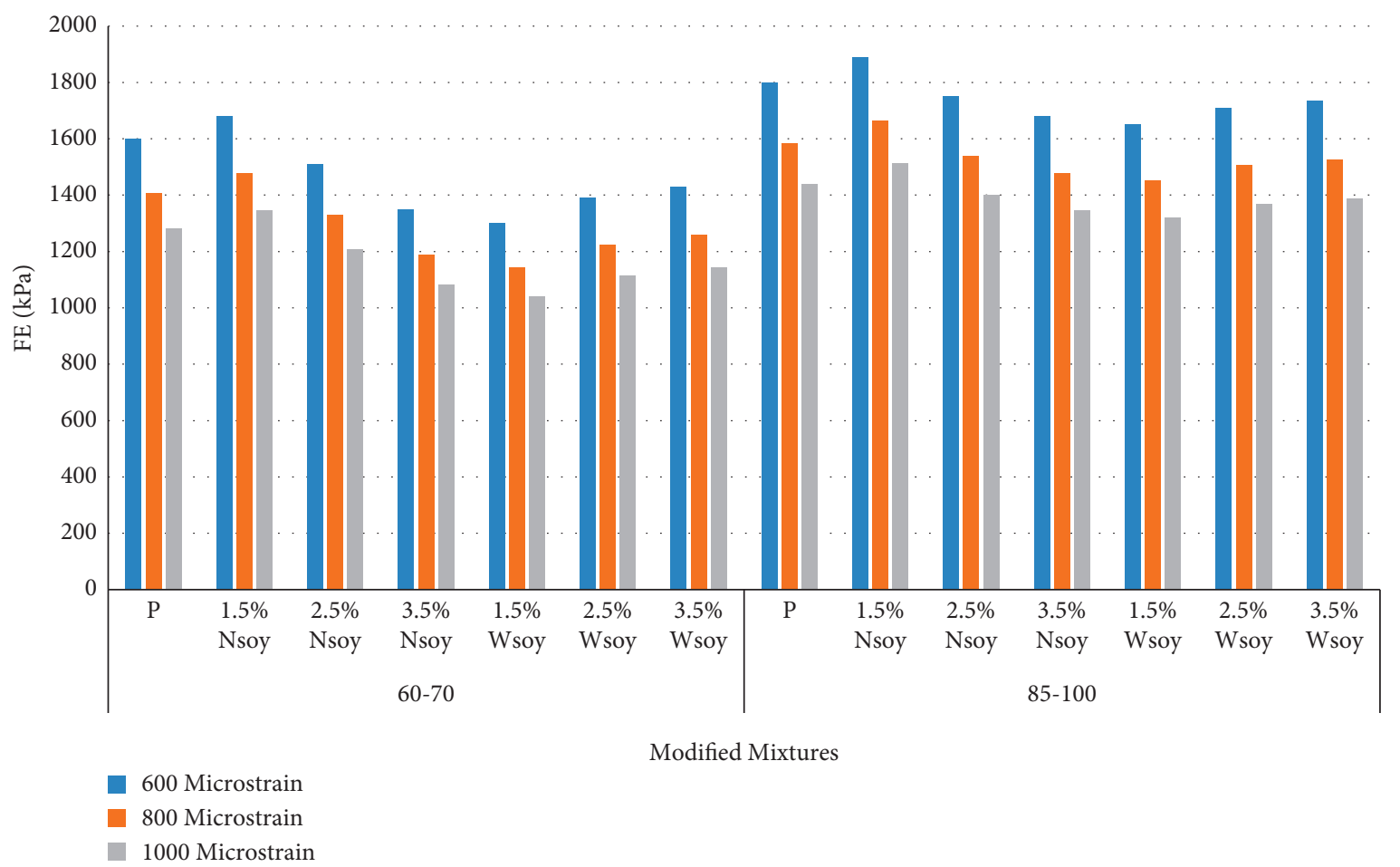

FIGURE 13: Unmodified and modified mixtures' fracture energy. 
TABLE 11: Two-way ANOVA: ITS versus additive and binder type.

\begin{tabular}{lccccc}
\hline Source & DF & Adj. SS & Adj. MS & $F$ value & $P$ value \\
\hline ITS & & & & & \\
Additive content & 7 & 63179902 & 21059967 & 5484.68 & 0.000 \\
Binder type & 2 & 3562852 & 1781426 & 463.94 & 0.000 \\
Interaction & 14 & 203194 & 33866 & 8.82 & 0.000 \\
Error & 24 & 92155 & 3840 & & \\
Total & 38 & 67038102 & & & \\
\hline
\end{tabular}

TABle 12: Two-way ANOVA: $M r$ versus additive and binder type.

\begin{tabular}{lccccc}
\hline Source & DF & Adj. SS & Adj. MS & $F$ value & $P$ value \\
\hline Additive content & 7 & 95769233 & 31923078 & 4014.23 & 0.000 \\
Binder type & 2 & 4214721 & 2107361 & 264.99 & 0.000 \\
Interaction & 14 & 1786681 & 297780 & 37.44 & 0.000 \\
Error & 24 & 190859 & 7952 & & \\
Total & 38 & 101961494 & & & \\
\hline
\end{tabular}

DF, degrees of freedom; MS, mean square; SS, sum of the squares.

TABLE 13: Two-way ANOVA: flow number versus additive and binder type.

\begin{tabular}{lccccc}
\hline Source & DF & Adj. SS & Adj. MS & $F$ value & $P$ value \\
\hline Additive content & 7 & 63179902 & 21059967 & 5484.68 & 0.000 \\
Binder type & 2 & 3562852 & 1781426 & 463.94 & 0.000 \\
Interaction & 14 & 203194 & 33866 & 8.82 & 0.000 \\
Error & 24 & 92155 & 3840 & & \\
Total & 38 & 67038102 & & & \\
\hline
\end{tabular}

$\mathrm{DF}$, degrees of freedom; MS, mean square; SS, sum of the squares.

TABLE 14: Two-way ANOVA: rut depth versus additive and binder type.

\begin{tabular}{lccccc}
\hline Source & DF & Adj. SS & Adj. MS & $F$ value & $P$ value \\
\hline Additive content & 7 & 38.7395 & 12.9132 & 409.73 & 0.000 \\
Binder type & 2 & 1.2293 & 0.6146 & 19.5 & 0.000 \\
Interaction & 14 & 0.1917 & 0.0319 & 1.01 & 0.440 \\
Error & 24 & 0.7564 & 0.0315 & & \\
Total & 38 & 40.9169 & & & \\
\hline
\end{tabular}

$\mathrm{DF}$, degrees of freedom; MS, mean square; SS, sum of the squares.

TABLE 15: Two-way ANOVA: fatigue life versus additive and binder type.

\begin{tabular}{lccccc}
\hline Source & DF & Adj. SS & Adj. MS & $F$ value & $P$ value \\
\hline Additive content & 7 & 56179848 & 31052349 & 7492.02 & 0.000 \\
Binder type & 2 & 2562765 & 1381412 & 263.23 & 0.000 \\
Interaction & 14 & 203192 & 28866 & 9.12 & 0.000 \\
Error & 24 & 92155 & 3840 & & \\
Total & 38 & 63038253 & & & \\
\hline
\end{tabular}

DF, degrees of freedom; MS, mean square; SS, sum of the squares.

variables that were highly affected by different warm-additive contents and warm additive-binder type interactions. Results showed that the warm additive had meaningful effects on MR, ITS, and FE; the same was true with the effects of the warm additive-binder type interaction.

\section{Conclusion}

This study aimed to produce WMA by using soybean cooking oil, which can be an environmentally and economically sustainable alternative. To assess the effect of soybean oil on the performance of SMA mixtures, some experiments, such as dynamic creep, ITS, Mr, wheel tracking, and FPB tests, were conducted. In addition, DSR, MSCR, and LAS tests were carried out for assessing the binders' rheological properties. Based on the findings, we can conclude the following:

(i) Addition of $3.5 \%$ oil leads to a decrease in the mixing and compaction temperature by about $8.1^{\circ} \mathrm{C}$ for mixtures containing new oil and $7.2^{\circ} \mathrm{C}$ for mixtures containing waste oil.

(ii) MSCR test results demonstrated a decrease in the rutting resistance when adding more percentages of soybean oil.

(iii) LAS test results showed that applying soybean enhances the virgin bitumen intermediate temperature performance. LAS test outcomes showed better performance of soybean oil at lower levels of strain.

(iv) Based on ITS test outcomes, the tensile strengths of soybean oil-modified binders were lower than the unmodified sample. This can be attributed to the decrease in the rigidity of the mixture through increasing oil. The waste oil modified mixtures have higher rigidity than the new ones, and the ITS of mentioned mixtures are higher.

(v) $M r$ test results show that using soybean oil causes $\mathrm{Mr}$ to decrease. It can be due to the decrease in the rigidity of the mixture via an increase of oil. The waste oil modified mixtures have higher rigidity than new ones, and the MR of mentioned mixtures are higher.

(vi) Adding soybean oil decreases the samples' permanent deformation resistance regarding the FN values of samples. The findings also indicated a decrement of the samples' stiffness and viscosity in the presence of oil, which in turn decreases the resistance of the samples against permanent deformation.

(vii) The outcomes of the wheel track test demonstrated soybean oil increases specimens' rut depth. This can be due to the decrease in the rigidity of the mixture by increasing the oil. The waste oil modified mixtures have higher rigidity than the new ones, and the MR of mentioned mixtures are higher.

(viii) The results of fatigue test demonstrated an improvement in the samples' intermediate temperature performance when adding $1.5 \%$ soybean oil.

(ix) There is no significant difference between the results of new and waste oil. This phenomenon makes it possible to reduce soybean oil production and consumption and instead reuse of frying oil 
(waste), which does not have any significant difference as compared to the results of chemical and physical properties.

(x) Based on the results, it can be suggested to use 1.5\% soybean oil in asphalt mixtures without compromising the performance of the mixture.

\section{Data Availability}

The data can be made available upon request to the corresponding author through email.

\section{Conflicts of Interest}

The authors declare that they have no conflicts of interest.

\section{References}

[1] J. Zhang, L. F. Walubita, A. N. M. Faruk, P. Karki, and G. S. Simate, "Use of the MSCR test to characterize the asphalt binder properties relative to HMA rutting performance-a laboratory study," Construction and Building Materials, vol. 94, pp. 218-227, 2015.

[2] Y. Wang, C. Wang, and H. Bahia, "Comparison of the fatigue failure behaviour for asphalt binder using both cyclic and monotonic loading modes," Construction and Building Materials, vol. 151, pp. 767-774, 2017.

[3] Y. Yidirim, "Polymer modified asphalt binders," Construction and Building Materials, vol. 21, no. 1, pp. 66-72, 2007.

[4] F. Zhang and J. Yu, "The research for high-performance SBR compound modified asphalt," Construction and Building Materials, vol. 24, no. 3, pp. 410-418, 2010.

[5] M. R. Ibrahim, H. Y. Katman, M. R. Karim, S. Koting, and N. S. Mashaan, "A review on the effect of crumb rubber addition to the rheology of crumb rubber modified bitumen," Annals of Materials Science \& Engineering, vol. 2013, Article ID 415246, 8 pages, 2013.

[6] D. Lo Presti and G. Airey, "Tyre rubber-modified bitumens development: the effect of varying processing conditions," Road Materials and Pavement Design, vol. 14, no. 4, pp. 888-900, 2013.

[7] C. H. Yuan, S. F. Wang, Y. Q. Zhu, H. B. Wang, and Y. Zhang, "Properties of the asphalts modified by typical recycled polyolefin," Polymer Materials Science \& Engineering, vol. 12, p. 81, 2012.

[8] M. A. Vargas, M. A. Vargas, A. Sánchez-Sólis, and O. Manero, "Asphalt/polyethylene blends: rheological properties, microstructure and viscosity modeling," Construction and Building Materials, vol. 45, pp. 243-250, 2013.

[9] Y. G. Xie, H. R. Yao, and J. Huang, "Structure and properties of POE modified asphalt," China Elastomerics, vol. 3, pp. 29-34, 2013.

[10] C. Fang, R. Yu, S. Liu, and Y. Li, "Nanomaterials applied in asphalt modification: a review," Journal of Materials Science \& Technology, vol. 29, no. 7, pp. 589-594, 2013.

[11] R. Babagoli, M. Hasaninia, and N. Mohammad Namazi, "Laboratory evaluation of the effect of Gilsonite on the performance of stone matrix asphalt mixtures," Road Materials and Pavement Design, vol. 16, no. 4, pp. 889-906, 2015.

[12] A. Ameli, R. Babagoli, M. Khabooshani, R. AliAsgari, and F. Jalali, "Permanent deformation performance of binders and stone mastic asphalt mixtures modified by SBS/ montmorillonite nanocomposite," Construction and Building Materials, vol. 239, Article ID 117700, 2020.

[13] A. Ameli, R. Babagoli, N. Norouzi, F. Jalali, and F. Poorheydari Mamaghani, "Laboratory evaluation of the effect of coal waste ash (CWA) and rice husk ash (RHA) on performance of asphalt mastics and Stone matrix asphalt (SMA) mixture," Construction and Building Materials, vol. 236, Article ID 117557, 2020.

[14] H. Ziari, R. Babagoli, and S. E. T. Razi, "The evaluation of rheofalt as a warm mix asphalt additive on the properties of asphalt binder," Petroleum Science and Technology, vol. 33, no. 21-22, pp. 1781-1786, 2015.

[15] B. Rezvan and Z. Hassan, "Evaluation of rutting performance of stone matrix asphalt mixtures containing warm mix additives," Journal of Central South University, vol. 24, no. 2, pp. 360-373, 2017.

[16] H. H. Kim and S.-J. Lee, "Effect of crumb rubber on viscosity of rubberized asphalt binders containing wax additives," Construction and Building Materials, vol. 95, pp. 65-73, 2015.

[17] H. H. Kim, M. Mazumder, and S.-J. Lee, "Recycling of aged asphalt binders with wax warm additives," Road Materials and Pavement Design, vol. 19, no. 5, pp. 1203-1215, 2018.

[18] Y. Yan, R. Roque, D. Hernando, and S. Chun, "Cracking performance characterisation of asphalt mixtures containing reclaimed asphalt pavement with hybrid binder," Road Materials and Pavement Design, vol. 20, no. 2, pp. 347-366, 2019.

[19] M. Sabouri, D. Mirzaiyan, and A. Moniri, "Effectiveness of Linear Amplitude Sweep (LAS) asphalt binder test in predicting asphalt mixtures fatigue performance," Construction and Building Materials, vol. 171, pp. 281-290, 2018.

[20] S. Ren, M. Liang, W. Fan et al., "Investigating the effects of SBR on the properties of gilsonite modified asphalt," Construction and Building Materials, vol. 190, pp. 1103-1116, 2018.

[21] B. V. Kök, M. Yilmaz, and M. Guler, "Evaluation of high temperature performance of SBS+Gilsonite modified binder," Fuel, vol. 90, no. 10, pp. 3093-3099, 2011.

[22] M. Ameri, D. Mirzaiyan, and A. Amini, "Rutting resistance and fatigue behavior of Gilsonite-modified asphalt binders," Journal of Materials in Civil Engineering, vol. 30, no. 11, Article ID 04018292, 2018.

[23] D. Mirzaiyan, M. Ameri, A. Amini, M. Sabouri, and A. Norouzi, "Evaluation of the performance and temperature susceptibility of gilsonite- and SBS-modified asphalt binders," Construction and Building Materials, vol. 207, pp. 679-692, 2019.

[24] L. Zhou, W. Huang, Y. Zhang, Q. Lv, C. Yan, and Y. Jiao, "Evaluation of the adhesion and healing properties of modified asphalt binders," Construction and Building Materials, vol. 251, Article ID 119026, 2020.

[25] Q. Lv, W. Huang, H. Sadek, F. Xiao, and C. Yan, "Investigation of the rutting performance of various modified asphalt mixtures using the Hamburg Wheel-Tracking Device test and Multiple Stress Creep Recovery test," Construction and Building Materials, vol. 206, pp. 62-70, 2019.

[26] J. Tang, C. Zhu, H. Zhang, G. Xu, F. Xiao, and S. Amirkhanian, "Effect of liquid ASAs on the rheological properties of crumb rubber modified asphalt," Construction and Building Materials, vol. 194, pp. 238-246, 2019.

[27] C. Qian, W. Fan, G. Yang, L. Han, B. Xing, and X. Lv, "Influence of crumb rubber particle size and SBS structure on properties of CR/SBS composite modified asphalt," Construction and Building Materials, vol. 235, Article ID 117517, 2020. 
[28] C. Qian and W. Fan, "Evaluation and characterization of properties of crumb rubber/SBS modified asphalt," Materials Chemistry and Physics, vol. 253, Article ID 123319, 2020.

[29] L. J. S. Souza, "Estudo das propriedades mecânicas de misturas asfálticas com cimento asfáltico de petróleo modificado com óleo de mamona (106 p)," Dissertação (Mestrado em Engenharia Civil e Ambiental)), Universidade Federal de Campina Grande, Campina Grande, Paraíba, PB, 2012.

[30] H. Ziari and R. Babagoli, "Evaluation of fatigue and rutting behavior of asphalt binder containing warm additive," $\mathrm{Pe}$ troleum Science and Technology, vol. 33, pp. 17-18, 2015.

[31] R. Babagoli and R. Mohammadi, "Laboratory evaluation of the effect of styrene-butadiene-styrene - montmorillonite nanocomposite on rheological behavior of bitumen and performance of stone matrix asphalt mixtures," Canadian Journal of Civil Engineering, vol. 44, no. 9, pp. 736-742, 2017.

[32] X. Wang, Y. Guo, G. Ji, Yi Zhang, J. Zhao, and H. Su, "Effect of biowaste on the high-and low-temperature rheological properties of asphalt binders," Advances in Civil Engineering, vol. 2021, Article ID 5516546, 14 pages, 2021.

[33] W. Ji, D. He, Di Wu, and M. K. Razi, "Research on the rheological properties of the plant oil pitch," International Journal of Chemical Engineering, vol. 2021, Article ID 5526113, 10 pages, 2021.

[34] W. Wang, S. Huang, Y. Qin, Y. Sun, R. Dong, and J. Chen, "Research on rheological properties of high-percentage artificial RAP binder with WMA additives," Advances in Materials Science and Engineering, vol. 2020, Article ID 1238378, 24 pages, 2020.

[35] J. Zhang and K. Li, "Characterization of warm mix agent and its influence on properties of SBS-modified asphalt," Advances in Materials Science and Engineering, vol. 2019, Article ID 2965964, 7 pages, 2019.

[36] Y. Hou, Y. Cai, Z. Zang, Z. Qian, and B. Zhao, "Dynamic characteristics of warm mix foamed asphalt mixture in seasonal frozen area," Advances in Materials Science and Engineering, vol. 2019, Article ID 1825643, 12 pages, 2019.

[37] J. Shi, W. Fan, Y. Lin, P. Zhao, and J. Ouyang, "Effects of surfactant warm-mix additives on the rheological properties of high-viscosity asphalt," Advances in Materials Science and Engineering, vol. 2020, Article ID 6506938, 11 pages, 2020.

[38] H. Tan, W. Xuan, and H. Wenke, "Microstructural mechanical analysis of warm-mixed reclaimed semiflexible pavement materials with interfacial weakening effect," Advances in Materials Science and Engineering, vol. 2021, Article ID 1055006, 10 pages, 2021.

[39] M. Irfan, Y. Ali, S. Ahmed, S. Iqbal, and H. Wang, "Rutting and fatigue properties of cellulose fiber-added stone mastic asphalt concrete mixtures," Advances in Materials Science and Engineering, vol. 2019, Article ID 5604197, 8 pages, 2019.

[40] E. R. Brown and L. A. Cooley, Designing Stone Matrix Asphalt Mixtures for Rut-Resistant Pavements, Transport Res Board, Washington, DC, US, 1999.

[41] A. L. Faxina, "Estudo da Viabilidade Técnica do USO do Resíduo de Óleo de Xisto Como Óleo Extensor EM Ligantes Asfalto-Borracha," (Tese (Doutorado em Engenharia Civil)), p. 286, Escola de Engenharia de São Carlos da Universidade de São Paulo (EESC/USP), São Carlos, São Paulo, SPEscola de Engenharia de São Carlos da Universidade de São Paulo (EESC/USP), 2006.

[42] B. J. Putman and S. N. Amirkhanian, Laboratory Evaluation of Anti-strip Additives in Hot Mix Asphalt, Publication FHWA-SC-06-07, FHWA, US Department of Transportation, 2006.
[43] A. Ameli, R. Babagoli, and M. Aghapour, "Laboratory evaluation of the effect of reclaimed asphalt pavement on rutting performance of rubberized asphalt mixtures," Petroleum Science and Technology, vol. 34, no. 5, pp. 449-453, 2016.

[44] T. Aashto, Standard Test Method for Multiple Stress Creep Recovery (MSCR) Test of Asphalt Binder Using a Dynamic Shear Rheometer, American Association of State Transport and Officials, Washington, DC, USA, 2012.

[45] T. P. Aashto, "Estimating damage tolerance of asphalt binders using the linear amplitude Sweep," Recuperado el, vol. 12, 2014.

[46] M. Vamegh, R. Babagoli, and D. Daryaee, "Effects of styrene butadiene styrene and Lucobite on stone mastic asphalt performance," Proceedings of the Institution of Civil Engineers - Construction Materials, pp. 1-10, 2020.

[47] R. Babagoli, M. Vamegh, and P. Mirzababaei, "Laboratory evaluation of the effect of SBS and Lucobite on performance properties of bitumen," Petroleum Science and Technology, vol. 37, no. 3, pp. 255-260, 2019.

[48] H. Ziari, A. G. Kaliji, and R. Babagoli, "Laboratory evaluation of the effect of waste plastic bottle (PET) on rutting performance of hot mix asphalt mixtures," Petroleum Science and Technology, vol. 34, no. 9, pp. 819-823, 2016.

[49] H. Ziari, R. Babagoli, M. Ameri, and A. Akbari, "Evaluation of fatigue behavior of hot mix asphalt mixtures prepared by bentonite modified bitumen," Construction and Building Materials, vol. 68, pp. 685-691, 2014 Oct 15.

[50] M. Rezaee, "Electrokinetic remediation of zinc and copper contaminated soil: a simulation-based study," Civil Engineering Journal, vol. 3, no. 9, pp. 690-700, 2017.

[51] M. Vamegh and M. Ameri, "Performance evaluation of fatigue resistance of asphalt mixtures modified by SBR/PP polymer blends and SBS," Construction and Building Materials, vol. 209, pp. 202-214, 2019.

[52] R. Roque, B. Birgisson, Z. Zhang, B. Sangpetngam, and T. Grant, Implementation of SHRP Indirect Tension Tester to Mitigate Cracking in Asphalt Pavements and Overlays, Florida Department of Transportation, Tallahassee, FL, US, 2002 May.

[53] American Association of State Highway and T. Transportation Officials, Standard Method of Test for Hamburg Wheel-Track Testing of Compacted Hot-Mix Asphalt (HMA), p. 324, Author, Washington, DC, US, 2008.

[54] AASHTO, Standard Method of Test for Determining the Fatigue Life of Compacted Hot Mix Asphalt (HMA) Subjected to Repeated Flexural Bending, AASHTO T 321-07 (Superseded), American Association of State Highway and Transportation Officials, Washington, DC, US, 2007.

[55] Z. Hassan, D. Hassan, B. Rezvan, and A. Ali, "Influence of bentonite additive on bitumen and asphalt mixture properties," Engineering and Technology, World Academy of Science, vol. 6, , 2012.

[56] R. C. F. Cella, M. A. B. Regitano-D'arce, and M. H. T. Spoto, "Comportamento do óleo de soja refinado utilizado em fritura por imersão com alimentos de origem vegetal," Ciência $e$ Tecnologia de Alimentos, vol. 22, pp. 111-116, 2002.

[57] L. C. F. L. Lucena, I. V. Silveira, and D. B. Costa, "Avaliação de ligantes asfálticos modificados com óleo da Moringa Oleífera Lam para uso em misturas mornas," Revista materia, vol. 21, no. 1, pp. 72-82, 2016.

[58] R. Babagoli, "Laboratory investigation of the performance of binders and asphalt mixtures modified by carbon nano tube, poly phosphoric acid, and styrene butadiene rubber," Construction and Building Materials, vol. 275, Article ID 122178, 2021. 
[59] N. Norouzi, A. Ameli, and R. Babagoli, "Investigation of fatigue behaviour of warm modified binders and warm-stone matrix asphalt (WSMA) mixtures through binder and mixture tests," International Journal of Pavement Engineering, vol. 22, pp. 1-10, 2019.

[60] H. Ziari, A. Goli, and A. Amini, "Effect of crumb rubber modifier on the performance properties of rubberized binders," Journal of Materials in Civil Engineering, vol. 28, no. 12, Article ID 04016156, 2016. 